\title{
Sovereign debt and bank fragility in Spain
}

\author{
Christiaan van der Kwaak $^{1}$ - Sweder van Wijnbergen ${ }^{1}$
}

Published online: 19 August 2016

(C) The Author(s) 2016. This article is published with open access at Springerlink.com

\begin{abstract}
In May 2012 the Spanish government announced a debt-financed recapitalization of the undercapitalized Spanish banking system. Although there was a wide consensus among economists and policymakers that this was key to solving Spain's economic troubles, both bank CDS and sovereign CDS further increased in the days following the announcement while lower bank CDS spreads were expected. Higher sovereign debt discounts deteriorated the fiscal position of the Spanish government. We propose a mechanism that can explain the events in Spain, namely the interaction whereby weak banks that are heavily exposed to risky domestic sovereign debt and weak government finances set off a negative amplification cycle: additional debt issue leads to higher sovereign debt discounts, resulting in capital losses on existing sovereign debt, deteriorating the capital base of banks, additional rounds of interest rate increases, a perverse amplification cycle substantially offsetting the initial recapitalization. We construct a DSGE model with balance-sheetconstrained financial intermediaries that finance private loans to the real economy, as well as sovereign debt subject to sovereign default risk. We calibrate the model to Spanish data, and find that our model is capable of matching the developments in the sovereign bond market in Spain in May/June 2012 quite well. We investigate an
\end{abstract}

We acknowledge the generous support of the Dutch Organization for Sciences, through the NWO Research Talent Grant No. 406-13-063. We thank Matthijs Knijnenburg for excellent research assistance.

Electronic supplementary material The online version of this article (doi:10.1007/s10290-016-0264-y) contains supplementary material, which is available to authorized users.

Sweder van Wijnbergen

s.j.g.vanwijnbergen@uva.nl

1 Tinbergen Institute, University of Amsterdam, Roetersstraat 11, 1018 WB Amsterdam, The Netherlands 
alternative policy, direct recapitalization by a foreign entity, such as the ESM, which avoids the negative sovereign risk amplification cycle.

Keywords Financial intermediation - Macrofinancial fragility - Fiscal policy · Sovereign default risk

JEL Classification E44 $\cdot$ E62 $\cdot$ H30

\section{Introduction}

In May 2012 the Spanish government announced a debt-financed recapitalization of the Spanish banking system, after the capital base of Spanish banks had been severely eroded following the end of the housing and construction boom of the 2000s. Conventional theory predicts that such a recapitalization should decrease bank CDS spreads, as happened in the US after the forced recapitalization of the larger US banks under the SCAP program of May 2009 (Hoshi and Kashyap 2014). And since the main risk to the Spanish government at the time seemed to be the risk of having to bail out the banking system, expectations were that CDS spreads on sovereign debt would fall as well. But contrary to predictions and apparently at variance with the US 2009 experience, CDS spreads for the banks, after a short temporary dip immediately following the recap announcement, continued their rise after the announcements, and so did sovereign CDS spreads, as can be seen from Fig. 1. This is remarkable since, under normal circumstances, a recapitalization increases loss absorption capacity of the bank concerned and should result in lower CDS spreads. In turn looser leverage constraints for banks should lead to increased loan supply to non-financial firms, eventually generating higher tax revenues for the government. In addition, better capitalized banks reduce the probability of the need for a fiscally costly bail out. Both factors would lead one to expect lower CDS spreads for sovereigns too. Yet in Spain CDS spreads continued their upward drift with consequent effects on interest rates, deteriorating the fiscal position of the Spanish government further. In June 2012, the Spanish government applied for emergency funding from the EFSF/ESM.

We will argue that the observed response can be explained by a negative feedback loop arising between undercapitalized banks that hold risky sovereign debt on the one hand and weak government finances on the other: ${ }^{1}$ issuing additional risky sovereign debt to fund a government bailout of commercial banks will lead to falling bond prices everything else equal; when commercial banks have a large exposure to this debt, they will therefore incur capital losses on these bonds. So falling bondprices imply that bank capital will take a hit, thereby limiting the headroom for new loans. Credit spreads and interest rates increase, and lead to lower private credit provision. Higher interest rates on government debt further increase the amount of debt the government needs to issue to fund its operations.But higher debt issue leads to a second round of bond price drops, and so on, setting off a vicious cycle whereby weak banks and weak sovereigns get into a negative

\footnotetext{
${ }^{1}$ As in Acharya et al. (2014) and Van der Kwaak and Van Wijnbergen (2014).
} 


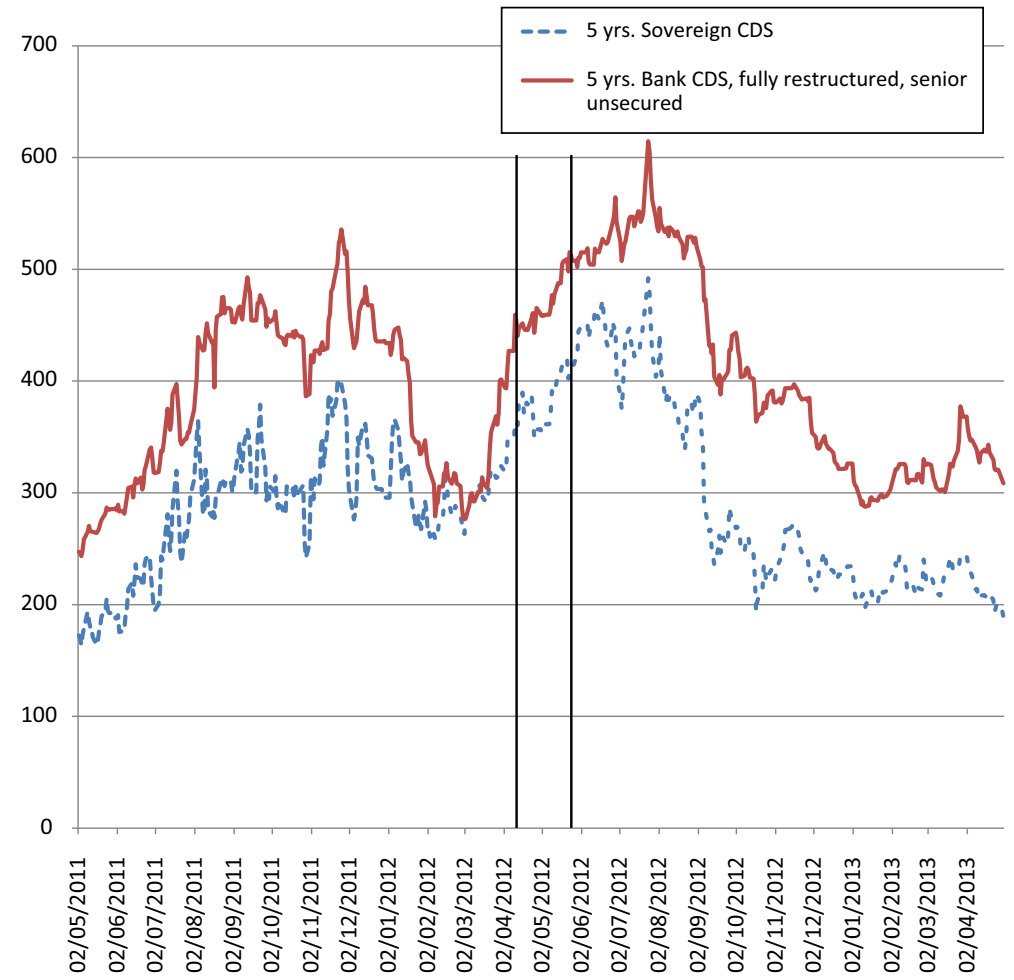

Fig. 1 Figure displaying CDS spreads. The blue slotted line depicts the CDS spread for Spanish sovereign debt with a maturity of 5 years, while the red solid line depicts the average CDS spread for Spanish banks (5 years, fully restructured, senior unsecured). The first vertical line is May 9th, 2012, at which the Spanish government announced the restructuring of the Spanish financial sector, while the second vertical line depicts June 25th, 2012, at which the eurogroup approved financial sector aid to Spain. Banks in the sample include Banco Popolare Espanol, Banco Santander, Caixa Bank and BBVA. Source: Datastream, own calculations (color figure online)

amplification cycle. In such an environment, the capital losses on existing holdings of sovereign debt can potentially offset the initial increase in bank capital due to the recapitalization by the government.

A key feature of this negative feedback loop is the fact that Spanish commercial banks were undercapitalized after the end of the housing and construction boom of the 2000s (International Monetary Fund 2011; Hoshi and Kashyap 2014). We therefore follow Gertler and Karadi (2011) and introduce balance-sheet-constrained financial intermediaries into a standard New-Keynesian DSGE model. ${ }^{2}$ We extend their setup in two directions: The first extension is to allow financial intermediaries to hold sovereign debt in addition to loans to the private sector. To allow for the possibility of capital losses on sovereign debt holdings, we introduce long-term maturity government bonds in a setup which is very similar to Woodford

\footnotetext{
2 Throughout the paper, we use 'commercial banks' and 'financial intermediaries' interchangeably to denote the same group of economic agents, which capture all kinds of credit institutions: commercial banks, savings banks, postbanks, and specialized credit institutions, among others.
} 
(1998, 2001). Such a setup avoids the escalating dimension of the state space that a less parsimonious approach to lengthening maturity would lead to. The second extension is to introduce endogenous sovereign default risk following Schabert and Van Wijnbergen (2014), which is a second channel that gives rise to potential capital losses on sovereign debt. The resulting default model is also used in Van der Kwaak and Van Wijnbergen (2014). The production sector contains price-stickiness and monopolistic competition to have real effects from monetary policy. Households consume, provide labor and save through deposits placed at financial intermediaries. Because our goal is to investigate whether the negative amplification cycles between weakly capitalized banks and weak sovereign finances can explain the failure of the Spanish government to recapitalize the Spanish financial sector, we calibrate the model to Spanish data by using parameters from the Bayesian estimation results by Burriel et al. (2010) where applicable, using in addition several specific sources for aggregate Spanish data (see the calibration appendix) to match moments in the data.

The main contribution of our paper is that we provide an explanation for the inability of the Spanish government to implement a debt-financed recapitalization of the Spanish financial sector in May/June 2012. To the best of our knowledge, we are the first paper to do so within a DSGE framework specifically calibrated to capture the dynamics of the Spanish economy. A second contribution of our paper is to investgiate the effectiveness of alternative recapitalization policies by foreign entities such as the EFSF/ESM.

Our first and main result is that we find that the above mentioned negative amplification cycle between undercapitalized banks with large holdings of risky sovereign debt and weak government finances explains the developments in Spanish bond markets in May/June 2012. A second result is that contrary to a debt-financed recapitalization by the sovereign, which is the standard macroeconomic policy prescription to tackle banking problems, an external recap by a foreign entity such as the EFSF/ESM can break the vicious cycle between weak banks and weak sovereigns. In such circumstances, commercial banks obtain the beneficial effects of a recapitalization, without incurring the negative feedback effects on bond prices, since the recapitalization does not add to domestic sovereign debt anymore.

Several papers in the literature have paid attention to this two-way feedback loop between undercapitalized banks and weak sovereigns. Empirical studies suggest that distress in financial markets can spill over to the sovereign debt market and vice versa (Acharya et al. 2014; Laeven and Valencia 2013; Haidar 2012; De Bruyckere et al. 2013; Alter and Schüler 2012), while the interdependence of banks and sovereigns has been shown to have grown over time (Alter and Beyer 2012). Models specifically designed to simulate the Spanish economy can be found in Burriel et al. (2010) and Fernandez-Villaverde and Ohanian (2010). Burriel et al. (2010) perform a Bayesian estimation with Spanish data for policy purposes. They do not focus on financial fragility so banks play no role in their set up. Fernandez-Villaverde and Ohanian (2010) do add financial frictions in a similar way as Bernanke et al. (1999) in an otherwise standard New-Keynesian closed economy model, but abstract from fiscal policy and government debt which plays a crucial role in our paper. 

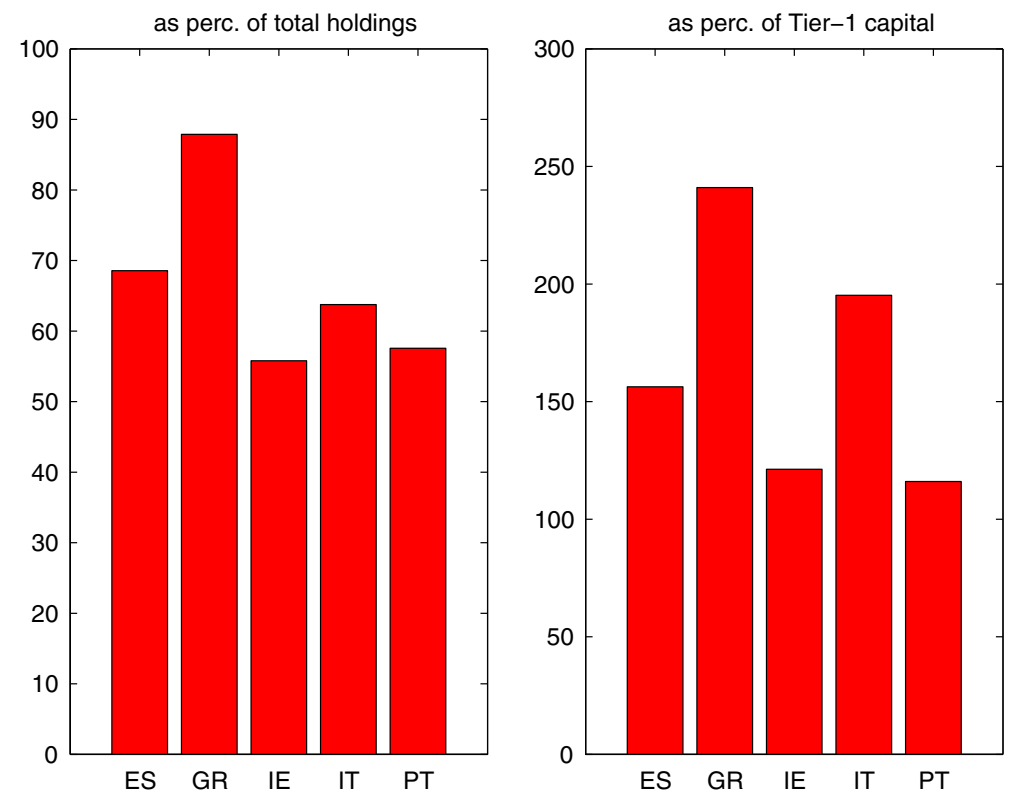

Fig. 2 Figure displaying sovereign debt exposure of European periphery banks to their own country's sovereign as a percentage of their total sovereign debt holdings (left), and as a percentage of their Tier-1 capital (right). The sample only contains Spanish banks that participated in the 2011 stress-test of the EBA (European Banking Authority). Source: European Banking Authority (2011), own calculations

\section{Stylized facts}

It is obviously important to investigate whether the feedback loop between weak banks and weak sovereigns can be so strong that the gains from a bank recapitalization are substantially eroded by the subsequent capital losses on sovereign debt issued for that very bank recapitalization. If Spain indeed fell victim to the two-way feedback loop between a distressed financial sector and increased sovereign credit risk, our model has important policy implications for countries that are in a similar position as Spain was before the attempted intervention. That would be most Southern European countries, such as Italy, Portugal and Greece, who also face issues related to sovereign debt sustainability, while commercial banks in these countries are heavily exposed to the domestic sovereign, as can be seen from Fig. 2, which shows the exposure to the domestic sovereign as a percentage of Tier-1 capital. Spanish banks have an exposure to Spanish sovereign debt of $150 \%$ of Tier-1 capital while Italian banks and Greek banks have an exposure of $200 \%$ respectively $250 \%$ of Tier- 1 capital. From these figures it is clear that domestic sovereign debt holdings of commercial banks are substantial and that stress in the sovereign debt market will seriously and negatively affect the financial sector. Countries like Greece, Italy and Portugal could face the same troubles should they attempt to recapitalize their financial sector through additional debt issue. The potential failure of such a recap severely limits the policy options for these governments, and might leave them in a situation where only a direct 
recapitalization by a foreign entity such as the EFSF/ESM is capable of breaking the feedback link between weak banks and weak sovereigns. Such a direct recapitalization is the final policy experiment we will perform with our model. A major conclusion is that without such Eurozone institutions, weak banks and weak governments would form a much more poisonous mix.

\section{Spain's financial sector problems}

\subsection{Run up to the sovereign debt crisis}

Spain experienced a booming economy in the decade leading up to the Great Recession of 2008-2009, with an annual average growth rate above $3.5 \%$. Strong economic growth and low interest rates led to a booming construction sector, with banks massively pooring funds into Spanish real estate. The subprime mortgage crisis spilled over from the United States into Europe in 2008 through the international banking system. Even though Spanish commercial banks had experienced relatively few losses during the global financial crisis of 2008-2009, due to a regulatory prohibition to invest in subprime mortgage products, the global financial crisis ended the housing boom that had endured in Spain during most of the 2000s. Falling real estate prices and losses on mortgages and construction loans resulted in significant bank losses, which first started to hit the Spanish financial sector in late 2010, with output falling after the first quarter of 2011. The burst of the real estate bubble left Spanish banks undercapitalized, which together with the broader sovereign debt crisis that had erupted in Greece in May 2010, started a vicious cycle exposing the negative link between losses on the balance sheets of banks, exploding borrowing costs, increases in public debt and a decrease in access to credit. A shrinking economy and vast unemployment were the result (International Monetary Fund 2011, 2014).

\subsection{The Spanish financial sector reforms of 2012-2013}

In response to the financial crisis which had substantially hurt its national banks, Spain committed in May 2012 to provide new capital to banks (through additional debt issue) in case they failed to raise it privately. At the time, the government expected that an injection of public capital in the hurting Spanish banks would restore financial markets confidence, and relax the leverage constraints of banks, creating more space on bank balance sheets for loans to the Spanish private sector. Expectations of a significant increase in Spanish public debt, however, put upward pressure on Spanish bond yields and drove bond prices down, as can be seen from Fig. 3: we clearly see financial markets reacting to announcements regarding financial aid for Spanish banks during this timespan, with the bond yield increasing by $1.2 \%$ and the CDS spread by 100 basis points. These are significant numbers, especially given the timespan of $<2$ months. When the Spanish government nationalized BFABankia on May 9th, both the yield and CDS spread experienced a sharp increase the very same day. The announcement of plans to restructure the bank with an additional capital injection of 19 billion Euro on May 23th reversed a downward movement in 


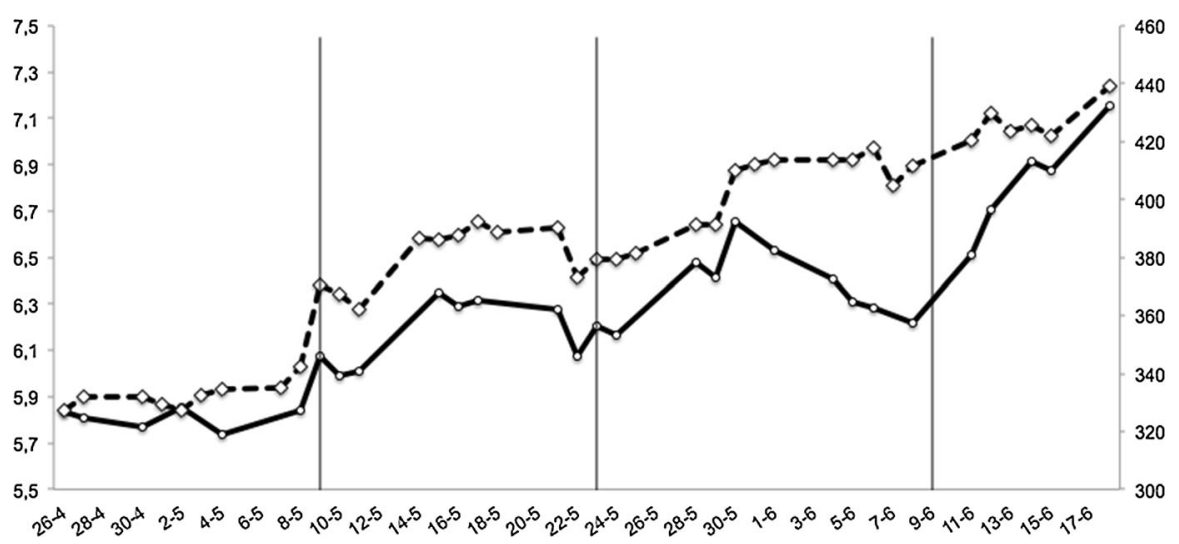

Fig. 3 Spanish 10 year government bond yield in per cent (solid line, left axis) and Spanish sovereign credit default swap in basis points (slotted line, right axis) from 26 April 2012 to 18 June 2012. Vertical lines represent: 9 May 2012, nationalization of BFA-Bankia; 23 May 2012, announcement of 19 billion euro capital injection in BFA-Bankia; 9 June 2012, Spain requests bailout of up to 100 billion euros. Source: Bloomberg, Datastream

the yield and CDS spread, indicating a new perception on the markets of increased risk. When it became clear at the beginning of June 2012 that Spain would not be able to fund a recapitalization on its own as a result of dampening demand for its debt papers, the yield and CDS spread again started to increase rapidly, driving borrowing costs to unsustainable levels, thereby preventing the Spanish government from obtaining the necessary funds for the recapitalization on the financial markets (Reuters 2012). Instead, the Spanish government was forced to apply for a loan from the EFSF/ESM (European Financial Stability Facility/European Stability Mechanism) to perform the much needed recapitalization of the financial sector (Eurogroup 2012). The announcement by the Spanish government that it would need up to 100 billion Euro from the EFSF/ESM on June 9th marked the start of an extended period of sharply increasing bond yields and CDS spreads. On June 25th, 2012 the Spanish government submitted an official request to obtain the necessary funds from the EFSF/ESM. This request was approved by the Eurogroup and the responsibility for the financing of the bank rescue programme was transferred to the newly established ESM (European Stability Mechanism) in November 2012.

The most important aspect of the programme was the recapitalization of banks with a capital shortfall. An independent stress test of the balance sheets of all Spanish banks identified ten banks that were unable to reach a Core Tier-1 capital ratio of $6 \%$ by the end of 2014 under an adverse scenario. The identified capital shortfalls totalled 56 billion euros, or $5.5 \%$ of GDP. Public capital injections in the first quarter of 2013 accounted for approximately $70 \%$ of these shortfalls, while the remaining capital shortfalls were addressed by bailing-in junior debt and private capital injections (International Monetary Fund 2014). Although the exact days in which the recapitalizations took place are unknown, a similar trend as in May/June 2012 can be discerned around January 2013, the month in which the bulk of the capital injections was completed. This can be seen in Fig. 4. After a drop in the yield 


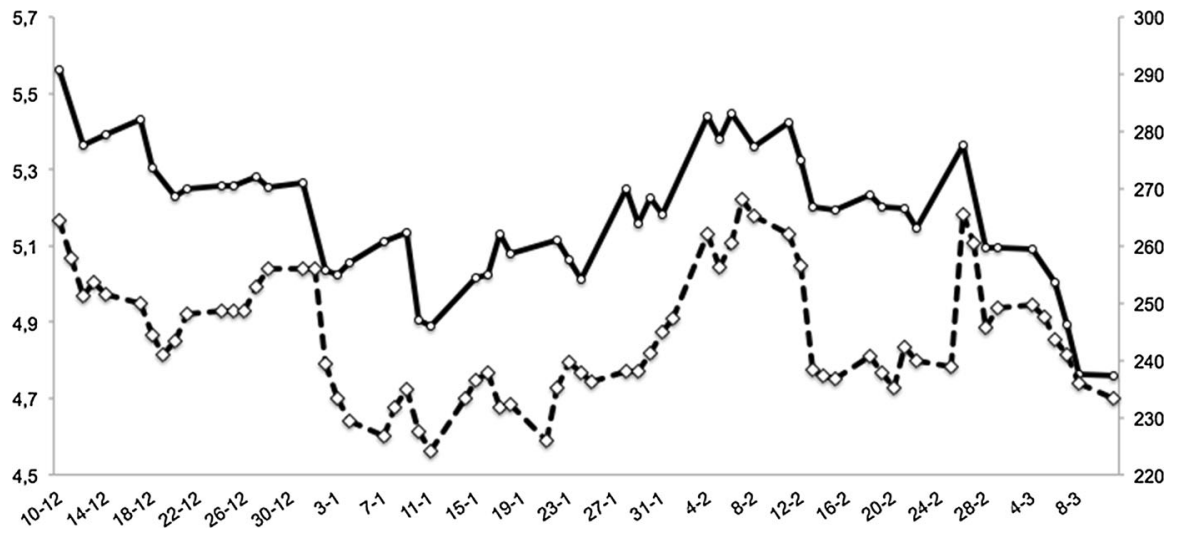

Fig. 4 Spanish 10 year government bond yield in per cent (solid line, left axis) and Spanish sovereign credit default swap (slotted line, right axis) from 10 December 2012 to 11 March 2013. Source: Bloomberg, Datastream

and CDS spread till January 11th, a slight upward trend is visible during the next month while the Spanish government increases its debt and transfers capital to its banks. After February, the yield and CDS spread shows a decreasing trend, indicating the positive effects of the recapitalization.

At present day, the Spanish sovereign is controlling owner of a significant share of the Spanish banking system. Partially as a result of the loans taken from the ESM, the ratio of government debt has increased from nearly 70-94 \% of GDP in the period from 2011 to 2013. In comparison, government debt amounted to only $36 \%$ of GDP before the start of the crisis in 2007 (Eurostat 2014).

\section{Model description}

We start from a standard New-Keynesian model with a private and a public sector, but extend it to include financial intermediation subject to frictions and a portfolio choice for commercial banks between corporate loans and long term government debt subject to sovereign default risk. ${ }^{3}$

\subsection{Households}

The household sector consists of a continuum of identical, infinitely lived households. Following Gertler and Karadi (2011), we assume that each household consists of both workers and bankers. A fraction $1-f$ are workers and earn wages that are transferred to the household. A fraction $f$ are bankers managing a financial intermediary from which the dividends are also transferred to the household. Each period a banker has a probability of $\theta$ to remain a banker in the next period. With probability $1-\theta$ the banker will exit the financial sector, in which case she transfers the net worth of her financial intermediary to the household and becomes a worker.

\footnotetext{
3 The model is closely related to the one developed in Van der Kwaak and Van Wijnbergen (2014).
} 
Every banker exiting the financial sector is replaced by a worker, who receives some net worth from the household to start operating a new financial intermediary. Exit and entry from the financial sector is such that the fraction of bankers and workers in the economy remains constant. The income from both bankers and workers are pooled, and equally divided among household members.

Households derive utility from consumption $c_{t}$ and disutility from providing labour $h_{t}$. Expected life-time utility is maximized subject to the household's budget constraint:

$$
\begin{aligned}
& \max _{\left\{c_{t+s}, h_{t+s}, d_{t+s}\right\}_{s=0}^{\infty}} E_{t}\left[\sum_{s=0}^{\infty} \beta^{s}\left(\log \left(c_{t+s}-v c_{t-1+s}\right)-\Psi \frac{h_{t+s}^{1+\varphi}}{1+\varphi}\right)\right] \\
& \text { s.t. } c_{t}+d_{t},+\tau_{t}=w_{t} h_{t}+\left(1+r_{t}^{d}\right) d_{t-1}+\Pi_{t},
\end{aligned}
$$

where $c_{t}$ is household consumption, $h_{t}$ labour supply, and $w_{t}$ the wage rate for workers. $d_{1-1}$ are household deposits from the previous period over which a net real interest rate $r_{t}^{d}$ is received, $\tau_{t}$ is a lump sum tax that is paid to the government and $\Pi_{t}$ are profits from both financial and non-financial firms owned by the household.

\subsection{Financial intermediaries}

Financial intermediaries hold assets in the form of claims issued by intermediate goods producers, government bonds and external bonds. External bonds are placed at the financial intermediaries in case of a recapitalization. The assets are financed through household deposits and equity (net worth). The balance sheet of the financial intermediary is given by

$$
p_{j, t}=n_{j, t}+d_{j, t},
$$

where $n_{j, t}$ represents the intermediary's net worth, $d_{j, t}$ funds deposited by households and $p_{j, t}$ the assets held by the intermediary. The asset side of the balance sheet is represented by:

$$
p_{j, t}=q_{t}^{k} s_{j, t}^{k}+q_{t}^{b} s_{j, t}^{b}+s_{j, t}^{e},
$$

with $q_{t}^{k}$ and $q_{t}^{b}$ denoting the price of claims on intermediate goods producers, respectively government bonds; $s_{j, t}^{k}$ and $s_{j, t}^{b}$ denote the amount of claims respectively bonds held, while $s_{j, t}^{e}$ represents the number of external bonds.

Each period, bankers face an exogenous probability $1-\theta$ that they have to exit the financial sector. In that case they pay out all net worth to the household, the ultimate owner of the intermediary. With probability $\theta$ intermediaries continue operating and retain all net worth. The continuation value $V_{j, t}$ of financial intermediary $j$ is therefore given by:

$$
V_{j, t}=E_{t}\left\{\beta \Lambda_{t, t+1}\left[(1-\theta) n_{j, t+1}+\theta V_{j, t+1}\right]\right\},
$$

where $\beta \Lambda_{t, t+1}$ denotes the household's stochastic discount factor. Following Gertler and Karadi (2011), we assume that corporate governance problems limit the extent to which the intermediary can leverage its net worth $n_{j, t}$. Each period, after the size 
and composition of the balance sheet have been determined, but before the shocks in the next period arrive, bankers have the possibility to divert assets. In that case, deposit holders force the financial intermediary into bankruptcy, but they can only recoup a fraction $1-\lambda_{t}^{a}$ of asset class $a \in\{k, b, e\}$. Hence bankers effectively keep a fraction $\lambda_{t}^{a}$ of asset class $a$. Deposit holders take this diversion possibility into account, and ensure that in equilibrium the gains from diverting assets are smaller than the continuation value of the financial intermediary.

$$
V_{j, t} \geq \lambda_{t}^{k} q_{t}^{k} s_{j, t}^{k}+\lambda_{t}^{b} q_{t}^{b} s_{j, t}^{b}+\lambda_{t}^{e} s_{j, t}^{e}
$$

This requirement effectively links the amount of net worth to the assets a financial intermediary can acquire through a leverage constraint $\phi_{t}$ (see "Appendix 1.1" for the formal derivation):

$$
q_{t}^{k} s_{j, t}^{k}+\left(\frac{\lambda_{t}^{b}}{\lambda_{t}^{k}}\right) q_{t}^{b} s_{j, t}^{b}+\left(\frac{\lambda_{t}^{e}}{\lambda_{t}^{k}}\right) s_{j, t}^{e}=\phi_{t} n_{j, t},
$$

An increase in $\lambda_{t}^{a}$ increases the effective gains from diversion of asset $a$ to the banker. As a consequence, deposit holders will reduce deposits, which causes a tightening of the leverage constraint. We will therefore model a financial crisis as a sudden increase in $\lambda_{t}^{a}$, see also Dedola et al. (2013). In particular, we assume the following processes for the diversion rates $\lambda_{t}^{a}$ :

$$
\begin{aligned}
\lambda_{t}^{k} & =\bar{\lambda}_{k}+\rho_{\lambda_{k}}\left(\lambda_{t-1}^{k}-\bar{\lambda}_{k}\right)+\varepsilon_{\lambda_{k}, t}, \\
\lambda_{t}^{b} & =\left(\frac{\bar{\lambda}_{b}}{\bar{\lambda}_{k}}\right) \lambda_{t}^{k}, \\
\lambda_{t}^{e} & =\bar{\lambda}_{e},
\end{aligned}
$$

where we assume that the ratio $\lambda_{t}^{b} / \lambda_{t}^{k}$ is constant across time, and denote it by $\bar{\lambda}_{b} / \bar{\lambda}_{k}$. In addition, we assume that $\varepsilon_{\lambda_{k}, t} \sim N\left(0, \sigma_{\lambda_{k}}^{2}\right)$.

Finally, the number of external bonds is determined by the size of externally financed capital injections to banks:

$$
s_{t}^{e}=s_{t-1}^{e}+\left(1-\kappa_{e}\right)\left(n_{t}^{g}-\tilde{n}_{t}^{g}\right),
$$

where $\kappa_{e}$ determines the share of the capital injection that is financed by the government, see Sect. 4.3. The optimization problem the financial intermediary faces, and its solution, is set out in "Appendix 1.1".

\subsection{Government}

The government issues long term "Woodford bonds", which are consols where the cashflow payment $r_{c}$ shrinks over time at a rate $\rho .{ }^{4}$ The shrinkage parameter $\rho$ determines the effective maturity of the bond. The bond price in period $t$ is denoted by

\footnotetext{
4 The advantage of this particular way of modeling long term debt is that longer maturity can be introduced without having to expand the number of state variables. See Woodford $(1998,2001)$.
} 
$q_{t}^{b}$. Clearly for such a security the stream of payments of one unit is equivalent to the cashflows generated by paying out $r_{c}$ in the first period and receiving a fraction $\rho$ of a similar new security going into the second period where the process repeats itself (see for more details the "Appendix 1.1.1"). So we get for the return on such a security:

$$
1+r_{t}^{b}=\frac{r_{c}+\rho q_{t}^{b}}{q_{t-1}^{b}}
$$

Furthermore government bonds are subject to sovereign default risk, which is introduced by assuming there is a maximum level of taxation, beyond which additional tax increases become politically unsustainable, as in Schabert and Wijnbergen (2014), and similar to the 'fiscal limit' in Davig et al. (2011). This fiscal limit, which is assumed to be constant across time, can be mapped one to one into a (constant) maximum level of debt, beyond which the government will (partially) default on its outstanding liabilities. We first take a look at the government budget constraint in case the government would honor all outstanding obligations. To finance its expenditures in period $t$, the government would issue $\tilde{b}_{t}$, the number of bonds that need to be issued to prevent a default, at price $q_{t}^{b}$ and levies a lump sump tax of $\tau_{t}$. In addition, it receives $\kappa_{e} \tilde{n}_{t}^{g}$ from financial intermediaries as repayment of past financial aid, where $\kappa_{e}$ determines the share of the capital injection that is financed by the government. $\kappa_{e}=1$ implies that the government pays for the full recapitalization, while $\kappa_{e}=0$ represents a situation in which the capital injection is completely done by an external party (e.g. the ESM). These funds are used for $g_{t}=\bar{g}$ government purchases, net worth provision (recapitalization) $\kappa_{e} n_{t}^{g}$ to financial intermediaries and refinancing of outstanding government liabilities $\left(1+r_{t}^{b}\right) q_{t-1}^{b} b_{t-1}$, where $r_{t}^{b}$ is the default exclusive net real return in period $t$ on bonds purchased in period $t-1$. The no default budget constraint would then be given by:

$$
q_{t}^{b} \tilde{b}_{t}+\tau_{t}+\kappa_{e} \tilde{n}_{t}^{g}=g_{t}+\kappa_{e} n_{t}^{g}+\left(1+r_{t}^{b}\right) q_{t-1}^{k} b_{t-1} .
$$

The lump sump tax depends on the level of outstanding debt and financial sector support and is given by the following tax rule:

$$
\tau_{t}=\bar{\tau}+\kappa_{b}\left(b_{t-1}-\bar{b}\right)+\kappa_{n} n_{t}^{g} ; \quad 0<\kappa_{b} \leq 1, \quad 0 \leq \kappa_{n} \leq 1,
$$

where $\bar{\tau}$ is the steady state tax level and $\bar{b}$ is the steady state level of debt. The feedback parameter of debt on taxes $\kappa_{b}$ must be strictly positive to obtain debt sustainability in the sense of satisfying the intertemporal budget constraint in the absence of defaults (Bohn 1998). ${ }^{5}$ The value of $\kappa_{n}$ determines whether aid to the financial sector is financed by tax increases, debt or a combination of the two. When $\tilde{b}_{t}$ is smaller than $b_{t}^{\max }$, actual government debt $b_{t}$ equals the no default level of government debt $\tilde{b}_{t}$. But when $\tilde{b}_{t}>b_{t}^{\max }$, the government will default over a fraction $\Delta_{t}$ of the debt, with $\Delta_{t}$ large enough to set the actual level of debt $b_{t}$ equal to the maximum level of debt $b_{t}^{\max }$, so we get:

\footnotetext{
${ }_{5}^{5}$ Note that this does not exclude a "mildly explosive" debt path, just a debt stock that grows at less than the rate of interest.
} 


$$
b_{t}=\min \left(\tilde{b}_{t}, b_{t}^{\max }\right)=b_{t}^{\max }-\max \left(b_{t}^{\max }-\tilde{b}_{t}, 0\right) .
$$

The second term has the payoff structure of a put option with underlying process $\tilde{b}_{t}$ and strike price $b_{t}^{\max }$. This approach is used by Claessens and van Wijnbergen (1993) in their evaluation of the Mexican Brady plan debt restructuring.

A few comments are in order. This approach to sovereign default falls under what Aguiar and Amador (2013) call non-strategic default. The sovereign defaults after an unanticipated large shock drives the debt over a maxumum level compatible with the maximum tax revenue cosntraint the sovereign faces. The defaults are not a strategic choice, as they are for example in Arellano (2008) and in much of the recent debt crisis literature surveyed in Aguiar and Amador (2013), our default model is closer in spirit to the debt overhang literature in corporate finance. Also, in line with that latter literature, defaults are partial, while most of the strategic default literature assumes default to be a 0-1 decision, once a sovereign defaults it defaults on all outstanding debt. However this is mostly an ad hoc assumption made to avoid having to endogenize post-default bargaining, and in striking contradiction of almost all actual sovereign defaults (Cruces and Trebesch 2013). Finally since we do not model default as the outcome of a strategic choice, there is no need to incorporate an explicit punishment mechanism (like exclusion of capital markets after a default). Our focus is on the bond price impact after an increase in ex ante sovereign default risk, rather than the losses arising from an actual default.

For numerical reasons we approximate the sharply kinked ex-post default rule (5) by the ex ante option pricing based valuation formula derived in Claessens and van Wijnbergen (1993) which closely approximates the kinked pay out curve for appropriately chosen parameters but avoids the discontinuity at $b_{t}^{\max }$ (see "Appendix 1.3"). When a default occurs, all creditors accept the discount $\Delta_{t}$ on the gross default exclusive return $1+r_{t}^{b}$. The default inclusive return $r_{t}^{b *}$ is then given by:

$$
1+r_{t}^{b *}=\left(1-\Delta_{t}\right)\left(1+r_{t}^{b}\right)
$$

The actual government budget constraint is given by:

$$
q_{t}^{b} b_{t}+\tau_{t}+\kappa_{e} \tilde{n}_{t}^{g}=g_{t}+\kappa_{e} n_{t}^{g}+\left(1-\Delta_{t}\right)\left(1+r_{t}^{b}\right) q_{t-1}^{b} b_{t-1} .
$$

The amount of net worth provision in period $t$ depends on the intermediairies' diversion rate of private loans $\lambda_{t}^{k}$ and is given by:

$$
n_{t}^{g}=x\left(\lambda_{t-l}^{k}-\bar{\lambda}_{k}\right) n_{t-1} ; \quad x \leq 0, \quad l \geq 0,
$$

where $l$ determines the number of lags with which the recapitalization is implemented. We assume that the repayment of government support will occur in the very far future, and hence we set $\tilde{n}_{t}^{g}=0$. 


\subsection{Production sector}

\subsubsection{Intermediate goods producers}

A continuum of intermediate goods producers, that face perfect competition, acquire capital $k_{i, t-1}$ from capital producers at the end of period $t-1$ for a price $q_{t-1}^{k}$ through a state-contingent loan $s_{i, t-1}^{k}=k_{i, t-1}$ from the financial intermediaries. Next period's profits can credibly be pledged to the intermediaries, as in Gertler and Kiyotaki (2010). After realization of the shocks, the producers hire labour $h_{i, t}$ at a wage $w_{t}$, and start producing intermediate goods with previous period capital $k_{i, t-1}$ and labor $h_{i, t}$ as input. After production, the intermediate goods producers pay a state-contingent net real return $r_{t}^{k}$ over claims issued in period $t$, with the following production technology:

$$
y_{i, t}=a_{t}\left(k_{i, t-1}\right)^{\alpha} h_{i, t}^{1-\alpha} .
$$

Total factor productivity $a_{t}$ is driven by exogenous $\mathrm{AR}(1)$ processes.

Output $y_{i, t}$ is sold to retail firms for a price $m_{t}$. The effective capital stock (after depreciation) is sold to the capital producers for a price $q_{t}^{k}$ and used to pay back the loans and a net return to the financial intermediaries. A more elaborate description of the maximization problem of the intermediate goods producers can be found in the Online Appendix.

\subsubsection{Capital producers}

Capital producers purchase the effective capital stock that is left after production (including depreciation), $(1-\delta) k_{t-1}$, from the intermediate goods producers. They also purchase an amount $i_{t}$ of final goods (see Sect. 4.4.4), and convert the old capital stock and newly purchased final goods into new capital. The newly produced capital stock $k_{t}$ is subsequently sold to the intermediate goods producers at the same price $q_{t}^{k}$ that was paid for the capital after production. The capital producers face convex adjustment costs, so that for every unit $i_{t}$ only $1-\Psi\left(l_{t}\right)$ units of capital are produced, with $l_{t}=i_{t} / i_{t-1}$ representing the change in the investment level. The expression for the capital stock after the capital producers have produced (or output of capital producers) is then:

$$
k_{t}=(1-\delta) k_{t-1}+\left(1-\Psi\left(l_{t}\right)\right) i_{t}, \operatorname{with} \Psi\left(l_{t}\right)=\frac{\gamma}{2}\left(l_{t}-1\right)^{2}
$$

\subsubsection{Retail firms}

A continuum of differentiated retail firms indexed by $i \in[0,1]$ transform intermediate goods $y_{i, t}$ into differentiated retail goods $y_{f, t}=y_{i, t}$ under perfect monopolistic competition. Each period, only a random portion $(1-\psi)$ of retail firms is allowed to reset their prices $P_{f, t}$, while the other firms can only (partially) index prices with previous period inflation, see Calvo (1983) and Yun (1996). Retail 
firms face the demand function $y_{f, t}=\left(P_{f, t} / P_{t}\right)^{-\epsilon} y_{t}$, with $\epsilon>1$ and price index $P_{t}^{1-\epsilon}=\int_{0}^{1} P_{f, t}^{1-\epsilon} d f$. The resulting first order conditions are standard, and can be found in the Online Appendix.

\subsubsection{Final goods producers}

Final goods producers purchase the differentiated retail goods $y_{f, t}$ to produce final goods. They face the following technology constraint:

$$
y_{t}^{(\epsilon-1) / \epsilon}=\int_{0}^{1} y_{f, t}^{(\epsilon-1) / \epsilon} d f,
$$

where $\epsilon$ represents the elasticity of substitution between goods bought from the retail firms. Final good producers operate in a perfectly competitive market. Hence they take prices as given, and sell their goods for the same price $P_{t}$. Final goods are sold to households and government for consumption, and to capital producers as input for investment.

\subsection{Central bank}

The nominal interest rate on deposits follows a standard Taylor rule:

$$
\begin{aligned}
r_{t}^{n}=\left(1-\rho_{r}\right)\left(\bar{r}^{n}+\kappa_{\pi}\left(\pi_{t}-\bar{\pi}\right)+\kappa_{y} \log \left(y_{t} / y_{t-1}\right)\right)+\rho_{r} r_{t-1}^{n}+\varepsilon_{r, t} & \\
& \kappa_{\pi}>1, \quad \kappa_{y}>0,
\end{aligned}
$$

where $\varepsilon_{r, t} \sim N\left(0, \sigma_{r}^{2}\right) . \vec{r}^{n}$ is the nominal interest rate in steady state, $\bar{\pi}$ the target level of inflation, and $\rho_{r}$ a smoothing parameter. The real return on deposits is given by:

$$
r_{t}^{d}=\left(1+r_{t-1}^{n}\right) / \pi_{t}-1
$$

\subsection{Equilibrium}

In equilibrium, there is clearing in all markets. For the goods markets this entails that aggregate supply equals aggregate demand:

$$
y_{t}=c_{t}+i_{t}+g_{t} .
$$

In the asset markets, the number of loans to the intermediate goods producers must equal the size of the capital stock and the number of bonds owned by financial intermediaries must equal the number of bonds issued by the government:

$$
\begin{aligned}
& s_{t}^{k}=k_{t}, \\
& s_{t}^{b}=b_{t} .
\end{aligned}
$$




\section{Calibration and matching business cycle statistics}

\subsection{Calibration}

The model described above is calibrated to match the Spanish economy as closely as possible. We will shortly explain the calibration targets (Table 1), while leaving a more detailed description of the calibration procedures for "Appendix 2". Several parameters are taken from Burriel et al. (2010), who perform a full blown Bayesian estimation of their model with data from the Spanish economy.

We assume the average lifetime of bankers to be equal to 24 quarters, resulting in a survival rate $\theta$ of 0.9583 . The maturity structure parameter $\rho$ is calibrated to reflect the weighted average maturity of government bonds in Spain between 1998 and 2008 , which is 6.1 years according to the OECD Stats database. The annual fixed real payment on long-term government bonds is set to $4.1 \%$, which is the 1998-2008 average of the interest rate on Spanish government bonds with a maturity of 10 years found in the Statistical Data Warehouse of the European Central Bank (2014).

The ratio of investment, government consumption and government debt over GDP are derived from Eurostat (2014). The 15-year average percentage of GDP that can be ascribed to private investment and government consumption is taken between 1994 and 2008. This results in steady state ratios of $22.6 \%$ for investments over GDP and $17.8 \%$ for government consumption over GDP. For the steady state credit spread $\Gamma$, the difference between the loans to non-financial corporations ("Total") and the deposit rate on "Household deposits redeemable at notice, Total, New Business" for the period between 2003 and 2007 is taken. Loan rates are not available before 2003. We end the sample at the end of 2007 to exclude data from the Great Recession. For the 2003-2007 period we arrive at an average annual credit spread in Spain of 188 basis points (annually), which amounts to a steady state quarterly spread of 47 basis points. We calibrate the diversion parameter for government bonds $\lambda_{t}^{b}$ to equal 0.5 times the diversion rate for private loans $\lambda_{t}^{k}$ in all periods, as in Gertler and Karadi (2013). To make sure that this value does not drive our results, we investigate the model response for different values of $\lambda_{t}^{b} / \lambda_{t}^{k}=\bar{\lambda}_{b} / \bar{\lambda}_{k}$ in the Online Appendix. We set the diversion rate for external bonds equal to zero, as these are assumed to be safe and liquid assets.

For the steady state leverage ratio we take the average ratio of consolidated equity to consolidated financial assets of the Spanish financial sector between 2001 and 2008 from the OECD Stats database. This results in a steady state leverage ratio of 5.1, which resembles the leverage ratio chosen by Gertler and Karadi (2011) of 4. Given the fact that the loans to the private sector are state-contingent, and thus more equity-like, more volatility is generated in bank net worth everything else equal. hence a lower steady state leverage ratio can compensate the higher volatility induced by the equity-like debt contracts, just as Gertler and Karadi (2013), who choose a lower steady state leverage ratio for the same reason. This leverage ratio results in a sovereign debt exposure of approximately $146 \%$ of net worth, which is close to the number in Fig. 2. 
The steady state ratio of government debt to annual output is set to 53.2, or $212.8 \%$ of quarterly output, which is the 1995-2008 average of the Spanish government debt to GDP ratio, while we set the maximum level of government liabilities at $60 \%$ of annual steady state GDP. A more detailed explanation of the calibration of the default parameters can be found in the Online Appendix.

The smoothing parameter of the nominal interest rate $\rho_{r}$ is set to 0.8 , which is in line with the literature. For the price-indexation parameter $\gamma_{P}$ with which retail firms that are not allowed to freely change prices can (partially) index prices with previous period inflation we take 0.241 following Gertler and Karadi (2011). In the Online Appendix we perform simulations for $\rho_{r}=0.4$ and $\gamma_{P}=0.7$, to make sure our results do not depend on the particular parameter value chosen for $\rho_{r}$ and/or $\gamma_{P}$.

Finally we choose $\rho_{\lambda_{k}}$ and $\sigma_{\lambda_{k}}$ for the $\operatorname{AR}(1)$ process that is driving the diversion rate $\lambda_{t}^{k}$. We calibrate these parameters to match the fall in Spanish quarterly output of $1 \%$ after December 2010, and to have the shock die out after approximately 10 quarters. We then find $\rho_{\lambda_{k}}=0.7$ and $\sigma_{\lambda_{k}}=0.025$.

\subsection{Matching business cycle statistics}

To assess whether the calibrated model can mimic the dynamics in the Spanish data, we compare basic business cycle statistics generated by the model with Spanish data over the period 2003-2007. We choose this period, because key variables like the loan rate, necessary for calculating the credit spread, are only available from 2003. We end the sample at the end of 2007 to exclude data from the Great Recession and the European sovereign debt crisis. As sovereign default risk was basically nonexistent during the 2003-2007 period, we perform the moment-matching exercise assuming sovereign default risk is absent, which we implement by setting the maximum level of government debt very far away from the steady state level of government debt.

We minimize the distance between the standard deviation of output, credit spread and investment from the data and the standard deviation of output, credit spread and investment generated from simulating the model for 20 quarters by adjusting the parameters of the two shocks in our model, namely the productivity shock parameters $\rho_{a}, \sigma_{a}$ and the monetary policy shock $\sigma_{r}$. We take the standard deviations of the cyclical components of Spanish real GDP and gross fixed capital formation to match the standard deviations of the cyclical components of output and investment from the simulated model. For the credit spread, we take the timeseries

Table 1 List of steady state calibration targets and source of calibration

\begin{tabular}{llll}
\hline Target & Definition & Value & Data source \\
\hline $\bar{i} / \bar{y}$ & Investment ratio & 0.226 & $1994-2008$ average \\
$\bar{g} / \bar{y}$ & Government spending ratio & 0.178 & $1994-2008$ average \\
$\bar{b} / \bar{y}$ & Government debt ratio & 2.128 & $1995-2008$ average \\
$\Gamma$ & Credit spread & 0.0047 & $2003-2007$ average \\
$\phi$ & Leverage ratio & 5.1 & $2001-2008$ average \\
\hline
\end{tabular}


Table 2 List of standard deviations of data and model (columns 2 and 3), and first order autocorrelations of data and model (column 4 and 5)

\begin{tabular}{llllll}
\hline & \multicolumn{2}{l}{ Standard deviation } & & \multicolumn{2}{l}{ Autocorrelations } \\
\cline { 2 - 3 } & Data & Model & & Data & Model \\
\hline GDP & 0.0025 & $0.0049[1.3151]$ & & 0.7009 & $0.6954[0.0450]$ \\
Credit spread & 0.0013 & $0.0016[0.6605]$ & & 0.6831 & $0.4513[-1.1933]$ \\
Investment & 0.0086 & $0.0211[1.5564]$ & & 0.5463 & $0.6995[1.2729]$ \\
Bank capital & 0.0311 & $0.0521[1.5962]$ & & 0.4947 & $0.4083[-0.4368]$ \\
\hline
\end{tabular}

$t$-statistics are reported between square brackets

described in Sect. 5.1. Simulated moments from the model are then compared to the data. In addition, we report the first order autocorrelations for the same variables. ${ }^{6}$

The results of this exercise are reported in Table 2 . We indicate the statistical significance of differences between the empirical moments and the simulated moments by reporting the associated $t$-statistics in square brackets. We see that the standard deviations for GDP, credit spread and investmentl are matched well by the model, as indicated by an absolute value of the $t$-statistic below 2 . This is not surprising, as these were the three moments we targeted in our simulation. In addition, we report the standard deviation of bank capital for both the data and the simulated model, and we find that the model matches the data in this dimension as well, as the accompanying $t$-statistic is below 2 in absolute value, in spite of the fact that this variable was not included in the target list.

We also inspect another aspect of the dynamics of our model, namely the first order autocorrelations for the same variables, in columns 4 and 5 of Table 2. Similar to the standard deviation for bank capital, we did not target these moments in the moment matching exercise. We nevertheless find that the first order autocorrelations of the simulated model and the data do not differ statistically significant, as the $t$ values for all variables are below 2 in absolute value. We conclude that our calibrated model captures the dynamics observed in the data reasonably well.

\footnotetext{
${ }^{6}$ For output and investment we take data from the Eurostat website. We take quarterly data that are seasonally and calendar adjusted, chain linked volumes (2010) in million euros. For the credit spread, we take the timeseries described in Sect. 5.1, which comes from the ECB website. Bank capital is also retrieved from the website of the ECB ("Capital and reserves"), which is a monthly timeseries. First we convert bank capital to real terms by dividing by the monthly CPI level in Spain. A single model simulation starts from the non-stochastic steady state and lasts for a 1020 periods. We discard the first 1000 observations as a burn-in. We perform 10,000 simulations for each gridpoint of the state space. Next we take the natural logarhitm of output, investment and bank capital for both the empirical and the simulated data, but not for the credit spread. The quarterly timeseries are obtained by taking an unweighted average of the monthly data, insofar as needed. We then find the cyclical components of the empirical data and the simulated data by applying the Hodrick-Prescott filter with a smoothing parameter of 1600 . The estimation consists of minimizing $g_{T}(\theta)^{\prime} g_{T}(\theta)$, where $g_{T}(\theta)$ is a vector with the difference between the standard deviation from the data and the simulations for output, credit spread and investment, and $T$ the number of observations, in our case 20. We restrict the search for the parameters $\left(\rho_{a}, \sigma_{a}, \sigma_{r}\right)$ in the following way. $0.8 \leq \rho_{a} \leq 0.999,0.001 \leq \sigma_{a} \leq 0.030$ and $0.001 \leq \sigma_{r} \leq 0.010$.
} 


\section{Recapitalizing the Spanish banking sector}

To analyze the surprizing responses to the Spanish attempts to rescue their banking system, we first simulate an internally financed bank recap. We compare the case with no additional government policy, and contrast the results with the case where the government issues additional debt to fund a recapitalization of the Spanish banking system (Sect. 6.1). Next we compare the debt-financed recap with the case where the recap is executed by an external party outside Spain, such as the EFSF or ESM (Sect. 6.2). We pin down the timing of our simulation by looking at the unfolding of the events in Spain. Losses on mortgages and construction loans first started to hit the Spanish financial sector in late 2010, with output falling after the first quarter of 2011. The first period in our simulations therefore coincides with the beginning of 2011. The actual recapitalization of the Spanish banks mainly took place at the start of 2013. We therefore set the recapitalization to occur 8 quarters after the start of the financial crisis. Since $70 \%$ of the total costs of the financial reform was accounted for by direct injections of public capital, we set the size of the recapitalization to 39.2 billion Euros. This is approximately equal to $3 \%$ of annual Spanish GDP before the start of the financial crisis. Our policy intervention will therefore in both simulations consist of a capital injection of $12 \%$ of quarterly steady state GDP, announced when the crisis erupts but implemented 8 quarters later. As to the financial crisis to which the policies are a response, we follow a different approach than most of the Financial Frictions literature sofar. Following Gertler and Karadi (2011), the crisis is typically modeled as a quality shock lowerering the effective stock of capital and its price, which in turn leads to capital losses on the banks' asset portfolio. In this setup the crisis originates in the real sector and spills over into the financial sector. Instead we let the original shock occur within the financial sector itself, with subsequent negative real sector effects through the ensuing credit tightening. In particular the original crisis is mimicked by a shock to the diversion parameter $\lambda_{t}^{k}$ for private loans, the closest we can come to a confidence shock in the financial sector. ${ }^{7}$

\subsection{Debt financed recaps}

The results from this first experiment are displayed in Fig. 5. The no intervention case is a financial crisis initiated through a positive one standard-deviation shock to the diversion rate for private loans $\lambda_{t}^{k}$. As a consequence, the diversion rate for government bonds is also shocked, since $\lambda_{t}^{b}=\left(\frac{\bar{\lambda}_{b}}{\bar{\lambda}_{k}}\right) \lambda_{t}^{k}$. This case is displayed by the solid blue line. The red slotted line represents the case where the same shock to $\lambda_{t}^{k}$ arrives, but now the government performs a debt-financed recapitalization equal to $3 \%$ of annual steady state output (and thus $12 \%$ of steady state quarterly output).

Consider first the no intervention case. When the financial crisis hits, the balancesheet-constraint of financial intermediaries becomes more binding, as a higher $\lambda_{t}^{k}$ and $\lambda_{t}^{b}$, respectively, imply that bankers can costlessly divert more private loans and

\footnotetext{
7 We thank a referee for this suggestion.
} 


\section{Financial crisis, no recap vs. debt financed recap}

(a)
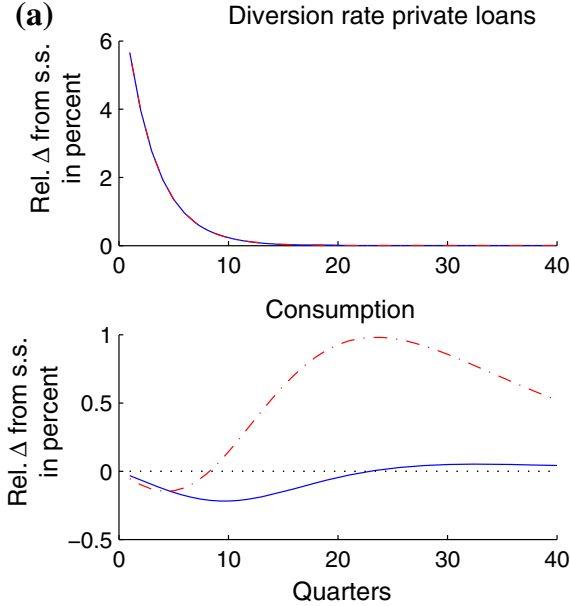

(b)
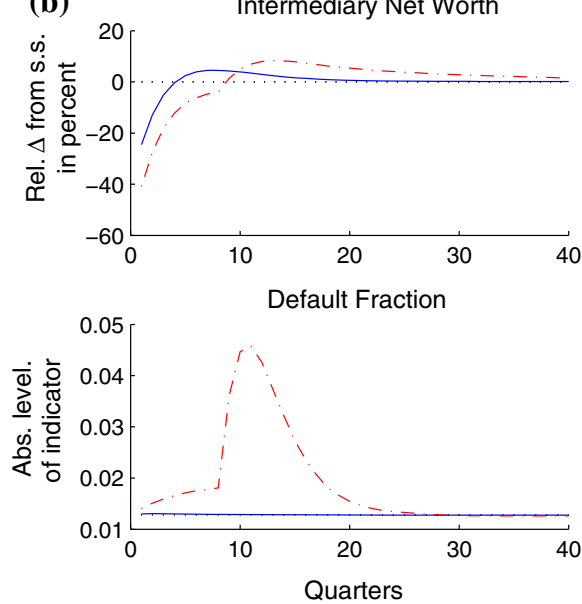

Output
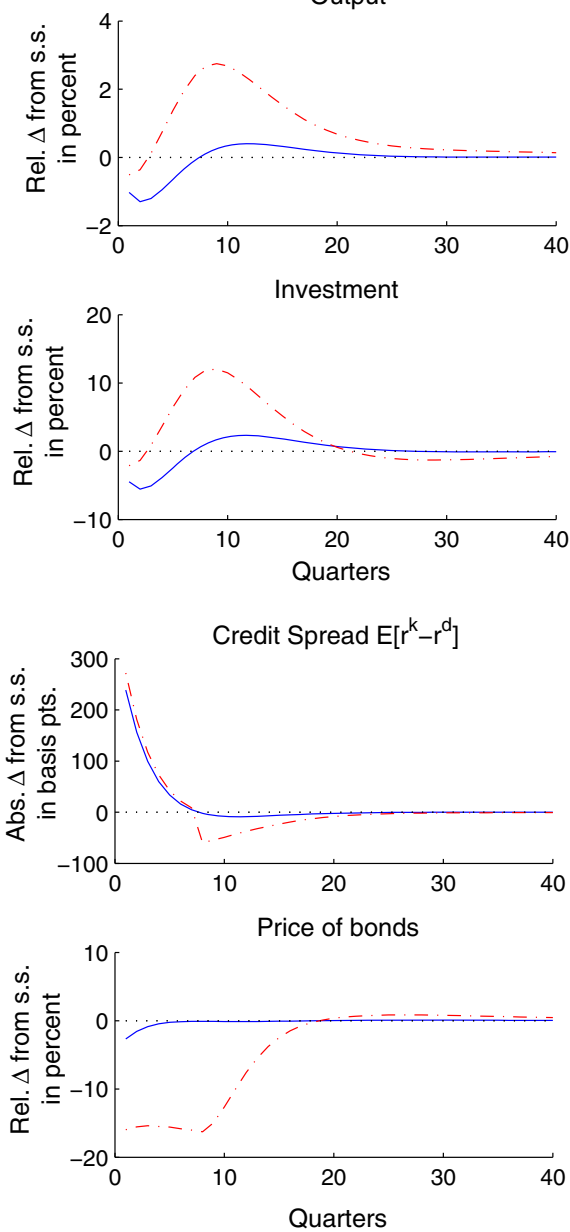

Fig. 5 Impulse response functions for the model runs including sovereign default risk and long term debt with a delayed recapitalization by the government ( red, slotted) of $12 \%$ of quarterly steady state output occurring eight quarters after the shock to the diversion rates $\lambda_{t}^{k}$ and $\lambda_{t}^{b}$, and for the simulations without additional government policy (blue, solid) (color figure online)

government bonds, respectively, everything else equal. A tighter balance-sheetconstraint pushes up credit spreads, which reduces the demand for private loans with a drop in the price of capital as a consequence. A lower resale price of capital further decreases the ex post return on the loans to intermediate goods producers (remember that the return on private loans (partially) consists of the proceeds from selling the capital used for production). A lower return on private loans reduces banks' net worth. But losses on private loans are not the only source of losses: balance sheet tightening also pushes up interest rates on sovereign debt and lowers 
bond prices, resulting in capital losses for existing bond holders. Bank equity value drops by more than $20 \%$ of steady state net worth, resulting in a drop in investment of $5 \%$ of steady state value, which reduces the capital stock. A lower capital stock results in lower marginal productivity of labor, pushing down wages and labor hired (both not shown), resulting in a drop in consumption and output.

The increased credit spread, however, increases bank profits from credit intermediation, and therefore restores bank equity after approximately 5 quarters, which allows an expansion of the balance sheet. Investment increases to $10 \%$ of its steady state level, and drives the medium-run recovery in output.

The announcement of a recapitalization 8 quarters into the future has dramatic consequences: the large recapitalization package (12\% of quarterly steady state GDP) pushes the debt level significantly up with lower bond prices and higher interest rates (on new debt) as a consequence. Higher interest rates on sovereign bonds reflect both the increased risk of sovereign default and arbitrage induced higher interest rates on bonds, as loan rates go up as credit spreads go up for corporates. The banks anticipate the increase in net worth 8 quarters from now due to the capital injection, but the size of the debt increase and the subsequent losses on the portfolio of bonds outstanding on the banks' balance sheet is so large that the losses on sovereign debt inflict capital losses larger than what is gained by the capital injection: net worth actually goes down instead of up when compared with the no intervention case, although there is a temporary dip in the credit spread at the time of the recap. The upfront drop in the bond price increases from $3 \%$ of the steady state bond price in the no recap case to more than $15 \%$ in the recap case.

The anticipation of a future recap, and hence a future alleviation of the balancesheet-constraint, together with an immediate fall in bondholdings due to lower bond prices, allows financial intermediaries to expand lending to the private sector. Credit spreads fall at the time of the intervention, and further accelerate the recovery. Investment increases to more than $10 \%$ above the steady state level of investment, and leads to a stronger recovery in GDP.

\subsection{Externally financed recapitalization}

Consider now the impact of a direct recap funded by an external party, such as the EFSF or the ESM, which would avoid the large increase in Spanish sovereign debt that caused the trouble in the runs discussed in the previous section. Member states of the Eurozone are still individually responsible for rescuing their banks, but they can receive funding for bank recaps from the ESM (European Stability Mechanism). However that would run into the problem outlined in the previous session as the sovereign debt would increase too, to another creditor perhaps, but debt levels would rise. An alternative has been considered after these problems did in fact emerge during the interventions in the Spanish banking crisis: one of the proposed solutions to break the vicious cycle between weak banks and weak sovereigns in the Eurozone is allowing the ESM to directly recapitalize banks that face a capital shortfall. Such a restructuring method would not force a sovereign to issue additional bonds to finance the recap, and recapitalize banks without the sovereign incurring additional debt. The positive effects from a bank recap remain, while the 
Financial crisis, debt financed recap vs. externally financed recap
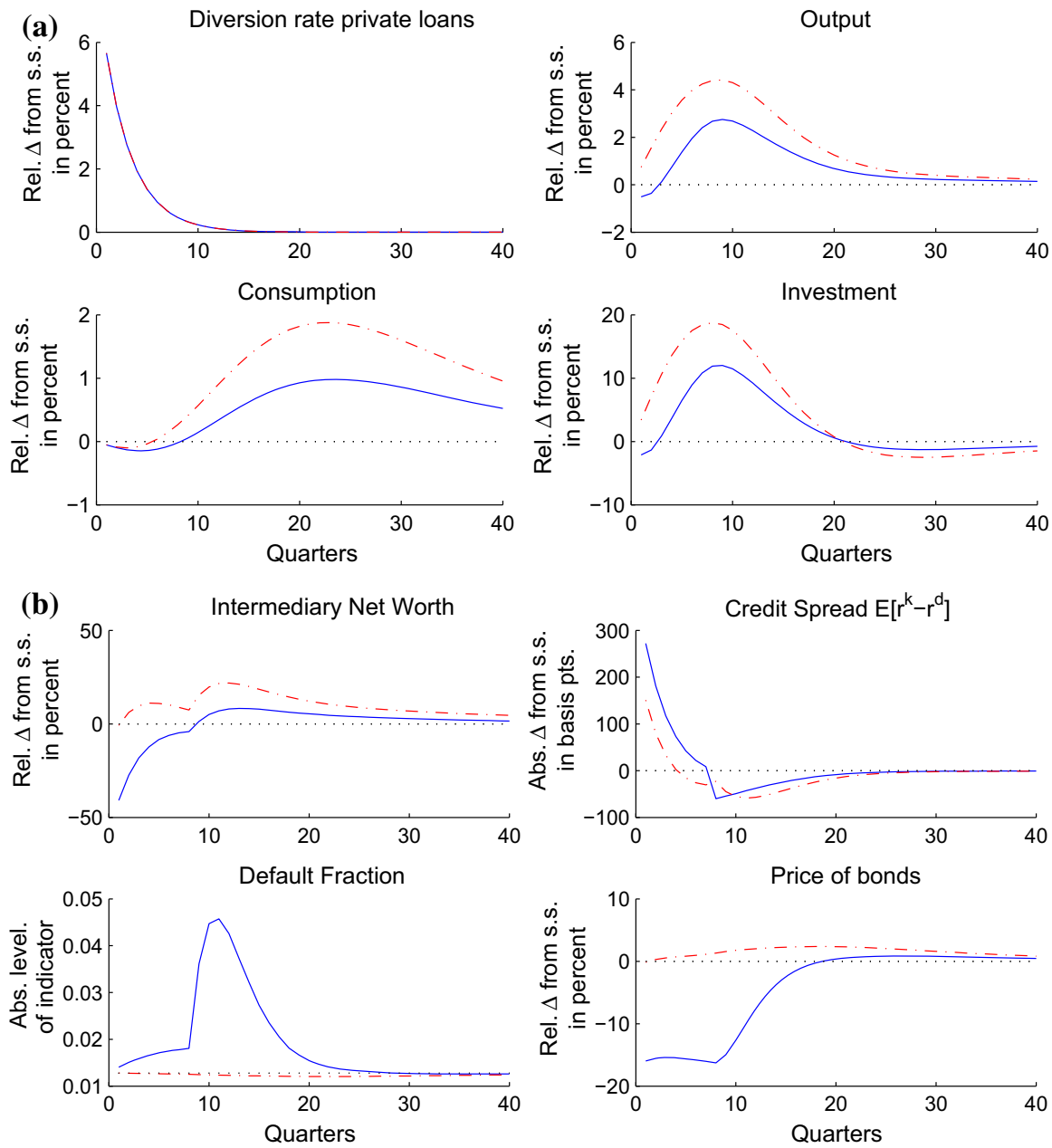

Fig. 6 The blue (solid) line represents the model runs with sovereign default with a delayed recapitalization financed with government bonds of $3 \%$ of annual steady state output occurring eight quarters after the shock to the diversion rates $\lambda_{t}^{k}$ and $\lambda_{t}^{b}$, and the model with a delayed external recapitalization (red, slotted) (color figure online)

negative consequences of increased sovereign default risk are absent. In order to simulate this scenario, we set the parameter $\kappa_{e}$ equal to zero. Banks are now recapitalized by an external party (ESM), and receive external assets $s_{t}^{e}$, together with an increase in net worth. Figure 6 shows the differential results, comparing the consequences of a debt financed intervention with an externally financed direct recapitalization by say the ESM:

The differential impact of an externally financed recapitalization is most clearly reflected in the different developments of the bond prices. When banks are 
recapitalized directly by an external party, the drop in the bond price from the direct recap is avoided altogether. Less debt issued by the government results in lower sovereign debt discounts, and hence lower or no capital losses on sovereign debt for existing bondholders. Net worth of the financial intermediaries is now above the steady state level of net worth over the entire time path and so the leverage constraint becomes less binding which in turn results in a lower credit spread and less crowding out. All this results in a level of investment, output and consumption that is consistently above the levels that are attained by a bond financed recapitalization in the first 20 quarters after the financial crisis starts.

This experiment shows that an external recapitalization has considerable advantages over a debt-financed recapitalization. So a direct recapitalization is beneficial from an economic point of view for the receiving country. Of course political factors might interfere, particularly if external support is linked to painful reforms. We abstain, however, from these political considerations, but conclude that for countries in severe sovereign debt trouble with banks deeply involved in the placement of sovereign debt, externally financed direct recapitalizations may be the only way a banking system can actually effectively be recapitalized.

\section{Discussion}

The funds for the recap were ultimately provided by the ESM in December 2012, but they consisted of loans/debt to the Spanish government who then implemented the actual recapitalizations (European Stability Mechanism 2012a, b, 2015). The development of the bond price around these announcements closely resembles the results from our simulations, in which the announcement of a (sizeable) recapitalization causes a drop in bond prices (or equivalently a rise in bond yields). Compare the data in Figs. 3 and 4 with our simulations in Fig. 5. While our simulations have the bond price drop immediately by more than $15 \%$ with respect to the steady state, the yield on the 10 year bond increases by $1.2 \%$ in Fig. 3 over the timespan of $<2$ months. Compared with the average interest rate of $4.1 \%$ on 10 year Spanish bonds over the period 1998-2008, this marks an increase of almost $30 \%$. Taking the interest rate at the start of May 2012 of $5.9 \%$ in Fig. 3, which already includes sovereign default risk (see the accompanying CDS spread), this still constitutes an increase of $20 \%$. The negative feedback mechanism between the sovereign and the domestic commercial banks, whereby an increase in sovereign debt to fund the recap causes bond prices to drop and further impair commercial bank balance sheets, therefore seems to be apparent in the data during the restructuring of the Spanish financial sector, which is also indicated by a marked increase in the sovereign CDS spread.

Our simulations show that bond prices are not recovering after the recap has been announced because of the pending debt issue. They only start to recover after the recapitalization has taken place. The (expected) return on bonds, which is similar to the 10 year bond yield in the data, jumps upwards at the moment the recap is implemented. A similar development can be seen in Fig. 4, where yields and CDS swaps increase during January, the month in which most of the recaps were 
implemented, only to fall after the implementation of the recap has been concluded at the beginning of February.

Apparently the main mechanism of our model, the negative amplification cycles arising between weak bank balance sheets and increased sovereign default risk due to additional debt issue, is capable of generating the patterns observed in the data. So it seems that amplification cycles are important in an environment where undercapitalized banks have a substantial exposure to risky domestic sovereign debt, as was the case in Spain in 2012 and in many other countries where governments face funding problems. The negative feedback mechanism might substantially affect the effectiveness of conventional recapitalization operations to the point where such a recap harms the recovery in the short run. In that case unconventional ways of recapitalizing the banking system are necessary. One of the options we have explored in this paper is a direct recapitalization by an external party: this way the negative feedback effects on bond prices, because of increased debt issuance and higher sovereign default risk, is absent, while bank capital is increased with subsequent positive effects on the real economy.

\section{Conclusion}

In May 2012 the Spanish government announced a debt-financed recapitalization of the Spanish banking system, after the capital base of Spanish banks had been severely damaged following the end of the housing and construction boom of the 2000s. Contrary to the standard theory, CDS spreads on both Spanish sovereign debt and Spanish banks went up, indicating that banking risks increased, in spite of the attempt to provide the banks with a higher capital base. Sovereign debt discounts increased dramatically in the days following the announcement, deteriorating the fiscal position of the Spanish government, which had already incurred several setbacks due to lower tax revenues after the end of the housing and construction boom.

We propose a mechanism that can explain the events in Spain: additional debt issue to finance a recapitalization of the banking sector increases sovereign default risk, and is translated in lower sovereign bond prices. Since the undercapitalized Spanish banks are heavily exposed to risky Spanish sovereign debt, lower bond prices translate into capital losses for those banks, thereby undermining the recap they were intended to fund. In repsonse, credit spreads and interest rates increase on non-financial corporate loans, but through arbitrage also on sovereign bonds. An additional fall in bond prices results, and so on, giving rise to a negative amplification cycle between weak commercial bank balance sheets and weak government finances.

To assess the relevance of this mechanism, we construct a DSGE model with balance-sheet-constrained financial intermediaries that finance private loans to the real economy, as well as sovereign debt with endogenously determined default risk and calibrate the model to Spanish data. We find that our model is capable of generating the negative amplification cycles between undercapitalized commercial banks and sovereign default risk: a pre-announced debt-financed recapitalization, calibrated to match the size of the Spanish recapitalization in January 2013, finds the 
bond price falling by almost $20 \%$ with respect to the steady state bond price, comparable to the $20 \%$ increase in the interest rate on 10-year Spanish sovereign debt in May 2012 after the announcement of the recap. We therefore conclude that the negative amplification cycle between weak banks and weak sovereigns can explain the events that unfolded in Spain in May/June 2012 and has probably played a major role during that tumultuous period.

Our analysis highlights the limits to the conventional approach to bank rescues when undercapitalized banks are heavily exposed to the risky sovereign debt of the government: a debt financed recap might backfire, and become ineffective. In that case alternative policies have to be considered, such as assistance by another actor with a stronger balance sheet. We look at one such approach, namely a direct recapitalization by a foreign entity such as the ESM. We find that the results of such an external recap are positive: bond prices do not experience the steep fall that occurs after a debt-financed recap, and there is less crowding out of private loans, leading to a faster recovery. Although the economic benefits of such an external assistance seem clear, political factors might of course complicate this option, vide the resistance by Germany to direct recaps by the ESM.

Open Access This article is distributed under the terms of the Creative Commons Attribution 4.0 International License (http://creativecommons.org/licenses/by/4.0/), which permits unrestricted use, distribution, and reproduction in any medium, provided you give appropriate credit to the original author(s) and the source, provide a link to the Creative Commons license, and indicate if changes were made.

\section{Appendix 1: Derivations}

\section{Appendix 1.1: Financial Sector}

The maximization problem of the financial intermediary is given by:

$$
\begin{gathered}
V_{j, t}=\underset{\max }{\operatorname{s.t.}} E_{t}\left\{\beta \Lambda_{t, t+1}\left[(1-\theta) n_{j, t+1}+\theta V_{j, t+1}\right]\right\}, \\
\quad V_{j, t} \geq \lambda_{t}^{k} q_{t}^{k} s_{j, t}^{k}+\lambda_{t}^{b} q_{t}^{b} s_{j, t}^{b}+\lambda_{t}^{e} s_{j, t}^{e},
\end{gathered}
$$

subject to the law of motion for net worth. $\beta \Lambda_{t, t+1}$ is the stochastic discount factor of the household, since the household is the ultimate owner of the intermediary. We conjecture the solution to be of the following form, and later check whether this is the case:

$$
V_{j, t}=v_{t}^{k} q_{t}^{k} s_{j, t}^{k}+v_{t}^{b} q_{t}^{b} s_{j, t}^{b}+v_{t}^{e} s_{j, t}^{e}+\eta_{t} n_{j, t} .
$$

The optimization problem implies the following Lagrangian:

$$
\mathcal{L}=\left(1+\mu_{t}\right)\left(v_{t}^{k} q_{t}^{k} s_{j, t}^{k}+v_{t}^{b} q_{t}^{b} s_{j, t}^{b}+v_{t}^{e} s_{j, t}^{e}+\eta_{t} n_{j, t}\right)-\mu_{t}\left(\lambda_{t}^{k} q_{t}^{k} s_{j, t}^{k}+\lambda_{t}^{b} q_{t}^{b} s_{j, t}^{b}+\lambda_{t}^{e} s_{j, t}^{e}\right) .
$$

where $\mu_{t}$ is the Lagrangian multiplier on the balance sheet constrain of the intermediaries. We get the following first order conditions: 


$$
\begin{aligned}
& s_{j, t}^{k}:\left(1+\mu_{t}\right) q_{t}^{k} v_{t}^{k}-\lambda_{t}^{k} \mu_{t} q_{t}^{k}=0 \Longleftrightarrow v_{t}^{k}=\frac{\lambda_{t}^{k} \mu_{t}}{1+\mu_{t}}, \\
& s_{j, t}^{b}:\left(1+\mu_{t}\right) q_{t}^{b} v_{t}^{b}-\lambda_{t}^{b} \mu_{t} q_{t}^{b}=0 \Longleftrightarrow v_{t}^{b}=\frac{\lambda_{t}^{b} \mu_{t}}{1+\mu_{t}}, \\
& s_{j, t}^{e}:\left(1+\mu_{t}\right) v_{t}^{e}-\lambda_{t}^{e} \mu_{t}=0 \Longleftrightarrow v_{t}^{e}=\frac{\lambda_{t}^{e} \mu_{t}}{1+\mu_{t}}, \\
& \mu_{t}:\left[\left(v_{t}^{k} q_{t}^{k} s_{j, t}^{k}+v_{t}^{b} q_{t}^{b} s_{j, t}^{b}+v_{t}^{e} s_{j, t}^{e}+\eta_{t} n_{j, t}\right)-\left(\lambda_{t}^{k} q_{t}^{k} s_{j, t}^{k}+\lambda_{t}^{b} q_{t}^{b} s_{j, t}^{b}+\lambda_{t}^{e} s_{j, t}^{e}\right)\right] \mu_{t}=0 .
\end{aligned}
$$

From the first order conditions we find that $v_{t}^{b}=\left(\frac{\lambda_{t}^{b}}{\lambda_{t}^{k}}\right) v_{t}^{k}$ and $v_{t}^{e}=\left(\frac{\lambda_{t}^{e}}{\lambda_{t}^{k}}\right) v_{t}^{k}$. Hence the incentive compatibility constraint of the bankers can be rewritten in the following way:

$$
\begin{gathered}
v_{t}^{k}\left(q_{t}^{k} s_{j, t}^{k}+\left(\frac{\lambda_{t}^{b}}{\lambda_{t}^{k}}\right) q_{t}^{b} s_{j, t}^{b}+\left(\frac{\lambda_{t}^{e}}{\lambda_{t}^{k}}\right) s_{j, t}^{e}\right)+\eta_{t} n_{j, t} \\
\geq \lambda_{t}^{k}\left(q_{t}^{k} s_{j, t}^{k}+\left(\frac{\lambda_{t}^{b}}{\lambda_{t}^{k}}\right) q_{t}^{b} s_{j, t}^{b}+\left(\frac{\lambda_{t}^{e}}{\lambda_{t}^{k}}\right) s_{j, t}^{e}\right) \\
\Longrightarrow q_{t}^{k} s_{j, t}^{k}+\left(\frac{\lambda_{t}^{b}}{\lambda_{t}^{k}}\right) q_{t}^{b} s_{j, t}^{b}+\left(\frac{\lambda_{t}^{e}}{\lambda_{t}^{k}}\right) s_{j, t}^{e} \leq \phi_{t} n_{j, t}, \\
\phi_{t}=\frac{\eta_{t}}{\lambda_{t}^{k}-v_{t}^{k}},
\end{gathered}
$$

where $\phi_{t}$ can be seen as the leverage constraint of the financial intermediary. The intuition for the leverage constraint is straightforward: a higher shadow value of assets $v_{t}^{k}$ implies a higher value from an additional unit of assets, which raises the continuation value of the financial intermediary, thereby making it less likely that the banker will steal. A higher shadow value of net worth $\eta_{t}$ implies a higher expected profit from an additional unit of net worth, while a higher fraction $\lambda_{t}^{a}$ implies that the banker can steal a larger fraction of assets, which induces the household to provide less funds to the banker, resulting in a lower leverage ratio everything else equal.

Substitution of the conjectured solution into the right hand side of the Bellman equation gives the following expression for the continuation value of the financial intermediary:

$$
\begin{aligned}
V_{j, t} & =E_{t}\left[\Omega_{t+1} n_{j, t+1}\right], \\
\Omega_{t+1} & =\beta \Lambda_{t, t+1}\left\{(1-\theta)+\theta\left[\eta_{t+1}+v_{t+1}^{k} \phi_{t+1}\right]\right\} .
\end{aligned}
$$

$\Omega_{t+1}$ can be thought of as a stochastic discount factor that incorporates the financial friction. Now substitute the expression for next period's net worth into the expression above: 


$$
\begin{aligned}
V_{j, t}=E_{t} & {\left[\Omega_{t+1} n_{j, t+1}\right] } \\
=E_{t} & {\left[\Omega _ { t + 1 } \left\{\left(r_{t+1}^{k}-r_{t+1}^{d}\right) q_{t}^{k} s_{j, t}^{k}+\left(r_{t+1}^{b}-r_{t+1}^{d}\right) q_{t}^{b} s_{j, t}^{b}\right.\right.} \\
& \left.\left.+\left(r_{t}^{e}-r_{t+1}^{d}\right) s_{j, t}^{e}+\left(1+r_{t+1}^{d}+\tau_{t+1}^{n}-\tilde{\tau}_{t+1}^{n}\right) n_{j, t}\right\}\right] .
\end{aligned}
$$

After combining the conjectured solution (13), with (16) we find the following first order conditions:

$$
\begin{aligned}
v_{t}^{k} & =E_{t}\left[\Omega_{t+1}\left(r_{t+1}^{k}-r_{t+1}^{d}\right)\right], \\
v_{t}^{b}=\left(\frac{\lambda_{t}^{b}}{\lambda_{t}^{k}}\right) v_{t}^{k} & =E_{t}\left[\Omega_{t+1}\left(r_{t+1}^{b}-r_{t+1}^{d}\right)\right], \\
v_{t}^{e} & =\left(\frac{\lambda_{t}^{e}}{\lambda_{t}^{k}}\right) v_{t}^{k}=E_{t}\left[\Omega_{t+1}\left(r_{t}^{e}-r_{t+1}^{d}\right)\right], \\
\eta_{t} & =E_{t}\left[\Omega_{t+1}\left(1+r_{t+1}^{d}+\tau_{t+1}^{n}-\tilde{\tau}_{t+1}^{n}\right)\right], \\
\text { with } \Omega_{t+1} & =\beta \Lambda_{t, t+1}\left\{(1-\theta)+\theta\left(v_{t+1}^{k} \phi_{t+1}+\eta_{t+1}\right)\right\},
\end{aligned}
$$

As described in section 4.1, each period a number of bankers the size of a fraction $(1-\theta) f$ of the households will become a worker and vice versa. The other bankers continue operating their financial intermediary. The aggregate net worth of these continuing intermediaries, abstracted from government aid and repayment, can therefore be given by

$$
n_{e, t}=\theta\left[\left(r_{t}^{k}-r_{t}^{d}\right) q_{t-1}^{k} s_{t-1}^{k}+\left(r_{t}^{b}-r_{t}^{d}\right) q_{t-1}^{b} s_{t-1}^{b}+\left(r_{t-1}^{e}-r_{t}^{d}\right) s_{t-1}^{e}+\left(1+r_{t}^{d}\right) n_{t-1}\right]
$$

Exiting bankers take the net worth of their intermediaries, $(1-\theta)$ of aggregate net worth, to the household, of which a share is provided as starting capital to entering bankers. This share is $\chi /(1-\theta)$ of the assets held by the indermediaries of exiting bankers. Adding financial sector support by the government and repayment of support, the total net worth of the financial sector is

$$
\begin{aligned}
n_{t}= & \theta\left[\left(r_{t}^{k}-r_{t}^{d}\right) q_{t-1}^{k} s_{t-1}^{k}+\left(r_{t}^{b}-r_{t}^{d}\right) q_{t-1}^{b} s_{t-1}^{b}+\left(r_{t-1}^{e}-r_{t}^{d}\right) s_{t-1}^{e}+\left(1+r_{t}^{d}\right) n_{t-1}\right] \\
& +\chi p_{t-1}+n_{t}^{g}-\tilde{n}_{t}^{g} .
\end{aligned}
$$

\section{Appendix 1.1.1: Long term government debt}

The government can issue debt which is long term, and has a maturity structure similar to Woodford $(1998,2001)$. A bond that is issued at price $q_{t-1}^{b}$ pays out a fixed cash flow (in real terms) of $r_{c}$ in period $t, \rho r_{c}$ in period $t+1, \rho^{2} r_{c}$ in period $t+2$ and so on. Hence in any given period the cash flow of a bond issued in period $t-1$ is a factor $\rho$ smaller than the cash flow of a bond issued in period $t$. Thus the return flows are equivalent to one first payment of the bond plus a fraction $\rho$ of a similar bond issued one period later: $r_{c}+\rho q_{t}^{b}$. The net real return in period $t$ on bond puchases $q_{t-1}^{b} b_{t-1}$ from period $t-1$ is therefore: 


$$
1+r_{t}^{b}=\frac{r_{c}+\rho q_{t}^{b}}{q_{t-1}^{b}}
$$

The duration of public debt is then equal to:

$$
\frac{\sum_{j=1}^{\infty} j \beta^{j}\left(\rho^{j-1} r_{c}\right)}{\sum_{j=1}^{\infty} \beta^{j}\left(\rho^{j-1} r_{c}\right)}=1 /(1-\beta \rho)
$$

\section{Appendix 1.2: Derivation of structural equations financial intermediaries in presence of sovereign default risk}

The introduction of sovereign default risk changes the equations for the financial intermediaries. In this section we show that the net worth of an individual intermediary is given by the same expression as the case with no default, except for the fact that we replace $r_{t}^{b}$ by $r_{t}^{b *}$. Hence we only have to replace $r_{t}^{b}$ in the equations governing the financial intermediaries by $r_{t}^{b *}$, and include the expression for $r_{t}^{b *}$ in the first order conditions. We start by observing that the funds obtained from selling the bonds in period $t+1$, that were purchased in period $t$, are reduced by $1-\Delta_{t+1}$, just as the fixed real payment $r_{c}$ per bond is reduced to $\left(1-\Delta_{t+1}\right) r_{c}$. Hence the law of motion for the net worth of an individual intermediary changes into the following equation:

$$
\begin{aligned}
n_{j, t+1}= & \left(1+r_{t+1}^{k}\right) q_{t}^{k} s_{j, t}^{k}+\left(1-\Delta_{t+1}\right) r_{c} s_{j, t}^{b}+\left(1-\Delta_{t+1}\right) \rho q_{t+1}^{b} s_{j, t}^{b} \\
& +\left(1+r_{t}^{e}\right) s_{j, t}^{e}-\left(1+r_{t+1}^{d}\right) d_{j, t}+n_{j, t+1}^{g}-\tilde{n}_{j, t+1}^{g} \\
= & \left(1+r_{t+1}^{k}\right) q_{t}^{k} s_{j, t}^{k}+\left(1-\Delta_{t+1}\right)\left(r_{c}+\rho q_{t+1}^{b}\right) s_{j, t}^{b} \\
& +\left(1+r_{t}^{e}\right) s_{j, t}^{e}-\left(1+r_{t+1}^{d}\right) d_{j, t}+n_{j, t+1}^{g}-\tilde{n}_{j, t+1}^{g} \\
= & \left(1+r_{t+1}^{k}\right) q_{t}^{k} s_{j, t}^{k}+\left(1-\Delta_{t+1}\right) \frac{\left(r_{c}+\rho q_{t+1}^{b}\right)}{q_{t}^{b}} q_{t}^{b} s_{j, t}^{b} \\
& +\left(1+r_{t}^{e}\right) s_{j, t}^{e}-\left(1+r_{t+1}^{d}\right) d_{j, t}+n_{j, t+1}^{g}-\tilde{n}_{j, t+1}^{g} \\
= & \left(1+r_{t+1}^{k}\right) q_{t}^{k} s_{j, t}^{k}+\left(1-\Delta_{t+1}\right)\left(1+r_{t+1}^{b}\right) q_{t}^{b} s_{j, t}^{b} \\
& +\left(1+r_{t}^{e}\right) s_{j, t}^{e}-\left(1+r_{t+1}^{d}\right) d_{j, t}+n_{j, t+1}^{g}-\tilde{n}_{j, t+1}^{g} \\
= & \left(r_{t+1}^{k}-r_{t+1}^{d}\right) q_{t}^{k} s_{j, t}^{k}+\left(r_{t+1}^{b *}-r_{t+1}^{d}\right) q_{t}^{b} s_{j, t}^{b}+\left(r_{t}^{e}-r_{t+1}^{d}\right) s_{j, t}^{e} \\
& +\left(1+r_{t+1}^{d}\right) n_{j, t}+\tau_{t+1}^{n} n_{j, t}-\tilde{\tau}_{t+1}^{n} n_{j, t},
\end{aligned}
$$

where $r_{t}^{b *}$ is given by:

$$
1+r_{t}^{b *}=\left(1-\Delta_{t}\right)\left(1+r_{t}^{b}\right)=\left(1-\Delta_{t}\right)\left(\frac{r_{c}+\rho q_{t}^{b}}{q_{t-1}^{b}}\right) .
$$

We replace $r_{t}^{b}$ by $r_{t}^{b *}$ in the equation for the shadow value of government bonds, and the law of motion of net worth: 


$$
\begin{aligned}
v_{t}^{b}= & E_{t}\left[\Omega_{t+1}\left(r_{t+1}^{b *}-r_{t+1}^{d}\right)\right], \\
n_{t}= & \theta\left[\left(r_{t}^{k}-r_{t}^{d}\right) q_{t-1}^{k} s_{t-1}^{k}+\left(r_{t}^{b *}-r_{t}^{d}\right) q_{t-1}^{b} s_{t-1}^{b}+\left(r_{t-1}^{e}-r_{t}^{d}\right) s_{j, t-1}^{e}+\left(1+r_{t}^{d}\right) n_{t-1}\right] \\
& +\chi p_{t-1}+n_{t}^{g}-\tilde{n}_{t}^{g} .
\end{aligned}
$$

The other equations for the financial intermediaries remain the same.

\section{Appendix 1.3: Approximation of the default function}

We can also write the debt level structure (5) in the following way:

$$
b_{t}=\min \left(\tilde{b}_{t}, b_{t}^{\max }\right)=b_{t}^{\max }-\max \left(b_{t}^{\max }-\tilde{b}_{t}, 0\right) .
$$

We can interpret the second term of the new debt level as the payoff of a put option at maturity with underlying process $\tilde{b}_{t}$ and strike price $b_{t}^{\max }$. The formula for $b_{t}$, however, does not have a defined derivative at $\tilde{b}_{t}=b_{t}^{\max }$. Therefore we apply an approximation for the payoff structure of the put option, and use the option pricing formula, which gives the price of the put option when time to maturity is equal to $T$, compounded riskfree interest rate $r$, and volatility of the underlying process $\sigma$. This is an approximation to the actual mapping from $\tilde{b}_{t}$ to $b_{t}$. The dashed line in Fig. 7 is the approximation to the actual mapping of $\tilde{b}_{t}$ to $b_{t}$. We then get the following approximation for $b_{t}$, with $\Phi(\cdot)$ denoting the standard normal $\mathrm{CDF}$, which is indeed continuous:

$$
\begin{gathered}
b_{t}=b_{t}^{\max }-\text { put }_{t}, \\
\text { put }_{t}=X e^{-r T} \Phi\left(-d_{2, t}\right)-S_{t} \Phi\left(-d_{1, t}\right), \\
d_{1, t}=\frac{\log (S / X)+\left(r+\frac{\sigma^{2}}{2}\right) T}{\sigma \sqrt{T}}, \\
d_{2, t}=\frac{\log (S / X)+\left(r-\frac{\sigma^{2}}{2}\right) T}{\sigma \sqrt{T}}, \\
X=b_{t}^{\max } \\
S_{t}=\tilde{b}_{t} .
\end{gathered}
$$

\section{Appendix 2: Calibration and moment-matching}

\section{Appendix 2.1: Calibration}

The model described above is calibrated to match the Spanish economy as closely as possible. The steady state calibration targets can be found in Table 3, which 
Debt structure mapping in presence of default risk

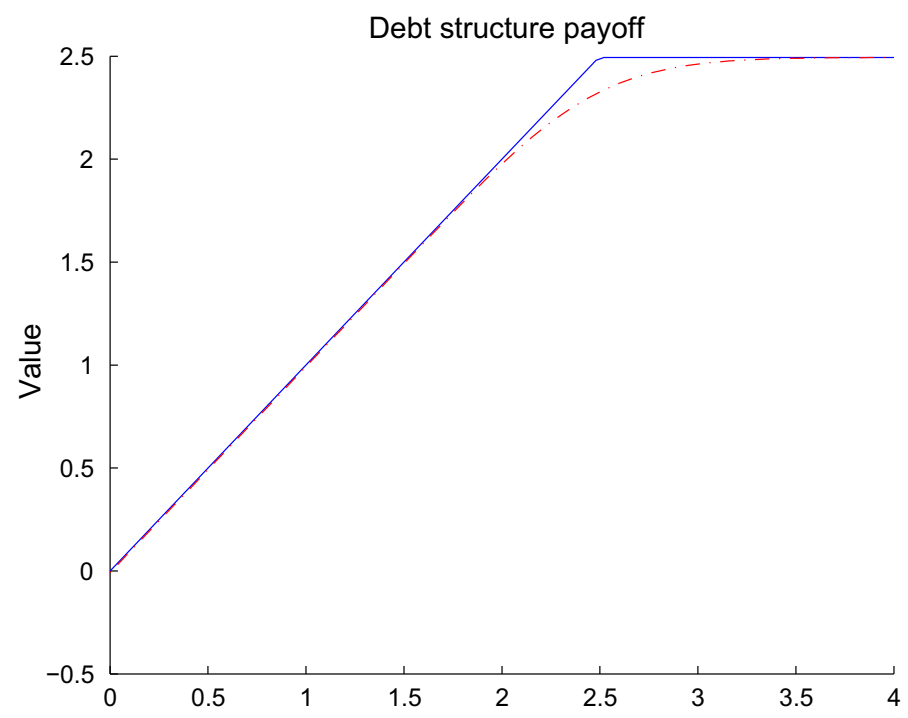

Fig. 7 Plot showing the mapping from the no default level of debt $\tilde{b}_{t}$ to the actual debt level $b_{t}$. The solid blue line is the actual mapping, while the dashed red line is an approximation to it, where option pricing formulas have been used

coincides with Table 1 in the main text. The calibrated parameter values can be found in Table 4. The subjective discount factor $\beta$, the share of effective capital in production $\alpha$ and the coefficients of the Taylor rule $\kappa_{\pi}$ and $\kappa_{y}$ are taken from Burriel et al. (2010). The smoothing parameter of the nominal interest rate $\rho_{r}$ is set to 0.8 , in line with the literature. We set the inverse Frisch elasticity of labour supply $\varphi$ equal to 0.1 , and adjust the disutility of labor coefficient $\Psi$ to have steady state labor supply of $1 / 3$. Parameters that have been approximated using Bayesian estimation include habit formation $v$, the elasticity of substitution between intermediate goods $\epsilon$, the Calvo probability $\psi$ and the investment adjustment parameter $\gamma$. Burriel et al. (2010) find a value for the Calvo probability $\psi$ of 0.898 . This, however, gives only explosive solutions. Therefore, the Calvo probability is reduced to 0.8 , for which the model has a unique, stable solution. The price-indexation parameter $\gamma_{P}$ is set to 0.241, following Gertler and Karadi (2011). We follow the value from Gertler and Karadi (2011) for the investment adjustment cost parameter $\gamma$.

We assume the average lifetime of bankers to be equal to 24 quarters, resulting in a survival rate $\theta$ of 0.9583 . The maturity structure parameter $\rho$ is calibrated to reflect the weighted average maturity of government bonds in Spain between 1998 and 2008 , which is 6,1 years according to the OECD Stats database. $\rho$ is therefore set to 0.97 (duration in quarters $=1 /(1-\beta \rho)$ ). The annual fixed real payment on longterm government bonds is set to $4.1 \%$, which is the 1998-2008 average of the interest rate on Spanish government bonds with a maturity of 10 years found in the Statistical Data Warehouse of the European Central Bank (2014). 
The ratio of investment, government consumption and government debt over GDP are derived from Eurostat (2014). The 15-year average percentage of GDP that can be ascribed to private investment and government consumption is taken between 1994 and 2008. This results in steady state ratios of 22.6 per cent for investments over GDP and 17.8 per cent for government consumption over GDP. This pins down the depreciation rate $\delta$ at a quarterly 3.55 per cent. The steady state ratio of government debt to output is set to 53.2 per cent, which is the 1995-2008 average of Spanish government debt to GDP ratio. For the steady state credit spread $\Gamma$, the difference between the loans to non-financial corporations ("Total") and the deposit rate on "Household deposits redeemable at notice, Total, New Business" for the period between 2003 and 2007 is taken. Loan rates are not available before 2003. We end the sample at the end of 2007 to exclude data from the Great Recession. For the 2003-2007 period we arrive at an average annual credit spread in Spain of 188 basis points (annually), which amounts to a steady state quarterly spread of 47 basis points. We calibrate the ratio of the diversion parameter for government bonds $\lambda_{t}^{b}$ and the diversion rate for private loans $\lambda_{t}^{k}$ to be constant and equal to 0.5 times, as in Gertler and Karadi (2013). To make sure that this value does not drive our results, we investigate the model response for different values of $\lambda_{t}^{b} / \lambda_{t}^{k}$ in the Online Appendix. We set the diversion rate for external bonds equal to zero, as we assume that these bonds are be safe and liquid assets that cannot be diverted. This results in a bank balance sheet of which approximately $25 \%$ consists of sovereign debt. The target value of gross inflation $\bar{\pi}$ is set to 1.005 , implying a $2 \%$ net inflation target, which is in line with the ECB inflation target.

There exist large differences between leverage ratios across the financial sector in Spain. Leverage ratios go as high as 34 for Banco Santander, whereas other financial institutions clearly have lower leverage ratios. To attempt to average across these different segments of the financial sectors, the average ratio of consolidated equity to consolidated financial assets of the Spanish financial sector is taken between 2001 and 2008 from the OECD Stats database. This results in a steady state leverage ratio of 5.1, which resembles the leverage ratio chosen by Gertler and Karadi (2011) of 4. Given the fact that the loans to the private sector are state-contingent, and thus more equity like, more volatility is generated in bank net worth everything else equal. hence a lower steady state leverage ratio can compensate the higher volatility induced by the equity like debt contracts, just as Gertler and Karadi (2013), who choose a lower steady state leverage ratio for the same reason. This leverage ratio results in a sovereign debt exposure of approximately $146 \%$ of net worth, which is slightly lower but close to the number in Fig. 2.

Table 3 List of steady state calibration targets and source of calibration

\begin{tabular}{llll}
\hline Target & Definition & Value & Data Source \\
\hline $\bar{i} / \bar{y}$ & Investment ratio & 0.226 & $1994-2008$ average \\
$\bar{g} / \bar{y}$ & Government spending ratio & 0.178 & $1994-2008$ average \\
$\bar{b} / \bar{y}$ & Government debt ratio & 2.128 & $1995-2008$ average \\
$\Gamma$ & Credit spread & 0.0047 & 2003-2007 average \\
$\phi$ & Leverage ratio & 5.1 & 2001-2008 average \\
\hline
\end{tabular}


Table 4 List of calibrated parameter values and source of calibration

\begin{tabular}{lll}
\hline Parameter & Definition & Value \\
\hline Households & & \\
$\beta$ & Subjective discount factor & 0.990 \\
$v$ & Degree of habit formation & 0.847 \\
$\Psi$ & Disutility weight of labour & 3.342 \\
$\varphi$ & Inverse Frisch elasticity & 0.100
\end{tabular}

Financial intermediaries

$\theta \quad$ Survival rate of bankers 0.9583

$\begin{array}{lll}\bar{\lambda}_{k} & \text { Steady state diversion rate private loans } & 0.4419\end{array}$

$\bar{\lambda}_{b} \quad$ Steady state diversion rate domestic bonds $\quad 0.2210$

$\bar{\lambda}_{e} \quad$ Steady state diversion rate external bonds $\quad 0$

$\chi \quad$ Transfer share to new bankers 0.0015

Production sector

$\begin{array}{lll}\alpha & \text { Effective capital share } & 0.362 \\ \epsilon & \text { Elasticity of substit. (goods) } & 8.577 \\ \psi & \text { Calvo prob. (price stickiness) } & 0.800 \\ \gamma_{P} & \text { Price-indexation } & 0.241 \\ \gamma & \text { Investment adjustment cost par. } & 1.728 \\ \delta & \text { Depreciation rate } & 0.0355\end{array}$

Policy parameters

$\rho \quad$ Government debt maturity par. $\quad 0.97$

$\begin{array}{lll}r_{c} & \text { Real payment to bondholder } & 4.1\end{array}$

$\begin{array}{cll}\rho_{r} & \text { Interst rate smoothing par. } & 0.8\end{array}$

$\kappa_{b} \quad$ Gov. debt feedback on taxes $\quad 0.05$

$\kappa_{\pi} \quad$ Inflation feedback on $r^{n} \quad 1.700$

$\begin{array}{lll}\kappa_{y} & \text { Output feedback on } r^{n} & 0.125\end{array}$

$\begin{array}{lll}\bar{\pi} & \text { Inflation rate target } & 1.005\end{array}$

AR(1) parameters

$\begin{array}{lll}\rho_{z} & \text { Productivity shock } & 0.9137\end{array}$

$\begin{array}{lll}\rho_{\lambda_{k}} & \text { Financial crisis shock } & 0.7\end{array}$

Shocks

$\begin{array}{lll}\sigma_{z} & \text { Std. productivity shock } & 0.0010\end{array}$

$\begin{array}{lll}\sigma_{r} & \text { Std. monetary policy shock } & 0.0010\end{array}$

$\begin{array}{lll}\sigma_{\lambda_{k}} & \text { Std. financial crisis shock } & 0.025\end{array}$

Default parameters

$\bar{\Delta} \quad$ Steady state share of default indicator $\quad 0.0128$

Option parameters

\begin{tabular}{llr}
$r$ & Risk-free interest rate & -0.0278 \\
$\sigma$ & Standard deviation & 0.4722 \\
$T$ & Time to maturity & 0.0591 \\
\hline
\end{tabular}




\section{Appendix 2.2: Default calibration}

In this section we describe the calibration when sovereign default risk is introduced. The calibration of the real economy is not affected by the introduction of sovereign default risk. For the financial sector, the steady state bond price $\bar{q}_{b}$ changes, and hence $\bar{b}$. We calibrate the maximum level of government liabilities $\bar{q}_{b} \bar{b}_{\text {max }} / \bar{y}$ to be at $70 \%$ of annual steady state GDP. Different values could have been chosen, but the main point of the paper is to show the mechanisms that interplay when debt levels get close to the maximum level of debt. We leave the steady state fraction of government liabilities $\bar{q}_{b} \bar{b} / \bar{y}$ at $53.2 \%$ annual steady state output target. The reason for this freedom is the fact that we have a new variable, the level of debt in case of no government debt $\tilde{b}_{t}$, and the steady state tax rate that we can adjust in order to still be able to hit our original targets. The steady state default probability is set at a rather conservative estimate of $\bar{\Delta}=0.0025$, which implies an annual default probability of $1 \%$, which is small given the observed bond spreads in the European periphery. We now apply calibration strategy 1 to find the parameters of the (option) approximation. Calibration strategy 1 cannot go further than a maximum level of government liabilities of $65 \%$ of annual steady state GDP. We therefore use the option parameters that we found for a maximum level of government liabilities equal to $70 \%$ of annual steady state GDP, and change to calibration strategy 2 which can still be applied, and calibrate the model at a maximum level of government liabilities of $60 \%$ of annual steady state GDP. This changes the steady state default probability to $\bar{\Delta}=0.0128$.

\section{References}

Acharya, V. V., Drechsler, I., \& Schnabl, P. (2014). A pyrrhic victory? Bank bailouts and sovereign credit risk. The Journal of Finance, 69(6), 2689-2739.

Aguiar, M. \& Amador, M. (2013). Sovereign debt: A review (NBER working papers). National Bureau of Economic Research, Inc.

Alter, A. \& Beyer, A. (2012). The dynamics of spillover effects during the european sovereign debt turmoil. Technical report, CFS working paper.

Alter, A., \& Schüler, Y. S. (2012). Credit spread interdependencies of european states and banks during the financial crisis. Journal of Banking \& Finance, 36(12), 3444-3468.

Arellano, C. (2008). Default risk and income fluctuations in emerging economies. American Ecxonomic Review, 98(3), 690-712.

Bernanke, B. S., Gertler, M., \& Gilchrist, S. (1999). The financial accelerator in a quantitative business cycle framework. In J. B. Taylor \& M. Woodford (Eds.), Handbook of macroeconomics (pp. 1341-1393). Amsterdam: Elsevier.

Bohn, H. (1998). The behavior of US public debt and deficits. The Quarterly Journal of Economics, 113(3), 949-963.

Burriel, P., Fernández-Villaverde, J., \& Rubio-Ramírez, J. F. (2010). Medea: A DSGE model for the Spanish economy. SERIEs, 1(1-2), 175-243.

Calvo, G. A. (1983). Staggered prices in a utility-maximizing framework. Journal of Monetary Economics, 12(3), 383-398.

Claessens, S., \& van Wijnbergen, S. (1993). Secondary market prices and Mexico's brady deal. The Quarterly Journal of Economics, 108(4), 967-982.

Cruces, J. J., \& Trebesch, C. (2013). Sovereign defaults: The price of haircuts. American Economic Journal: Macroeconomics, 5(3), 85-117. 
Davig, T., Leeper, E. M., \& Walker, T. B. (2011). Inflation and the fiscal limit. European Economic Review, 55(1), 31-47.

De Bruyckere, V., Gerhardt, M., Schepens, G., \& Vander Vennet, R. (2013). Bank/sovereign risk spillovers in the European debt crisis. Journal of Banking \& Finance, 37(12), 4793-4809.

Dedola, L., Karadi, P., \& Lombardo, G. (2013). Global implications of national unconventional policies. Journal of Monetary Economics, 60(1), 66-85.

Eurogroup (2012). Eurogroup statement on Spain. http://www.consilium.europa.eu/uedocs/cms_Data/ docs/pressdata/en/ecofin/130778.pdf.

European Banking Authority (2011). 2011 EU-wide stress test results.

European Central Bank (2014). website.

European Stability Mechanism (2012a). Faq-Financial assistance for Spain.

European Stability Mechanism (2012b). Financial assistance facility agreement.

European Stability Mechanism (2015). Spain's exit.

Eurostat (2014). Quarterly government debt.

Fernandez-Villaverde, J. \& Ohanian, L. (2010). The Spanish crisis from a global perspective (Working papers 2010-03). FEDEA.

Gertler, M., \& Karadi, P. (2011). A model of unconventional monetary policy. Journal of Monetary Economics, 58(1), 17-34.

Gertler, M., \& Karadi, P. (2013). QE 1 versus 2 versus 3 : A framework for analyzing large-scale asset purchases as a monetary policy tool. International Journal of Central Banking, 9(1), 5-53.

Gertler, M., \& Kiyotaki, N. (2010). Financial intermediation and credit policy in business cycle analysis. In B. M. Friedman \& M. Woodford (Eds.), Handbook of monetary economics (pp. 547-599). Amsterdam: Elsevier.

Haidar, J. I. (2012). Sovereign credit risk in the Eurozone. World Economics, 13(1), 123-136.

Hoshi, T., \& Kashyap, A. K. (2014). Will the US and Europe avoid a lost decade? Lessons from Japan's post crisis experience. IMF Economic Review, 63(1), 110-163.

International Monetary Fund (2011). IMF country report no. 11/215.

International Monetary Fund (2014). Spain: Financial sector reform final progress report. IMF country report, (14/59).

Laeven, L., \& Valencia, F. (2013). Systemic banking crises database. IMF Economic Review, 61(2), $225-270$.

Reuters (2012). Spain may recapitalize bankia with government debt, 27 May 2012. http://www.reuters. com/article/2012/05/27/us-spain-bankia-idUSBRE84Q0FB20120527.

Schabert, A., \& van Wijnbergen, S. J. G. (2014). Sovereign default and the stability of inflation-targeting regimes. IMF Economic Review, 62(2), 261-287.

Van der Kwaak, C., \& Van Wijnbergen, S. (2014). Financial fragility, sovereign default risk and the limits to commercial bank bail-outs. Journal of Economic Dynamics and Control, 43, 218-240.

Woodford, M. (1998). Public debt and the price level. Unpublished manuscript, Columbia University.

Woodford, M. (2001). Fiscal requirements for price stability. Journal of Money, Credit and Banking, 33(3), 669-728.

Yun, T. (1996). Nominal price rigidity, money supply endogeneity, and business cycles. Journal of Monetary Economics, 37(2-3), 345-370. 